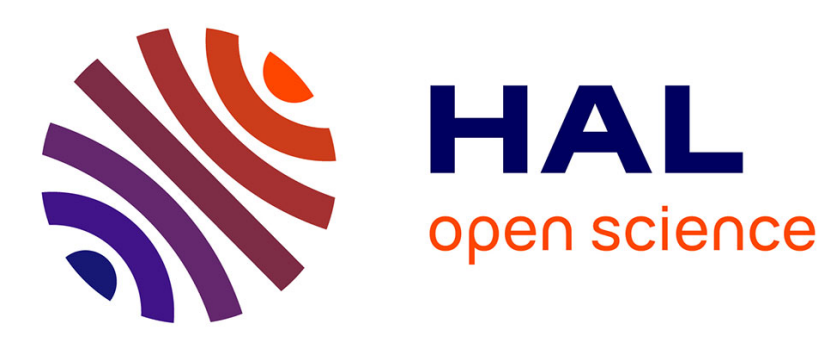

\title{
Critical components of biofilm models for engineering practice
}

\author{
J.P. Boltz, E. Morgenroth, Doris Brockmann, C. Bott, W.J. Gellner, P.A. \\ Vanrolleghem
}

\section{- To cite this version:}

J.P. Boltz, E. Morgenroth, Doris Brockmann, C. Bott, W.J. Gellner, et al.. Critical components of biofilm models for engineering practice. WWTmod2010 - 2nd IWA/WEF Wastewater Treatment Modelling Seminar, Young Water Professionals committee (YWP). INT., Mar 2010, Mont Saint-Anne, Canada. hal-01190424

\section{HAL Id: hal-01190424 https://hal.science/hal-01190424}

Submitted on 1 Sep 2015

HAL is a multi-disciplinary open access archive for the deposit and dissemination of scientific research documents, whether they are published or not. The documents may come from teaching and research institutions in France or abroad, or from public or private research centers.
L'archive ouverte pluridisciplinaire HAL, est destinée au dépôt et à la diffusion de documents scientifiques de niveau recherche, publiés ou non, émanant des établissements d'enseignement et de recherche français ou étrangers, des laboratoires publics ou privés. 


\title{
Critical Components of Biofilm Models for Engineering Practice
}

\author{
J.P. Boltz ${ }^{1}$, E. Morgenroth ${ }^{2}$, D. Brockmann ${ }^{3}$, C. Bott ${ }^{4}$, W.J. Gellner ${ }^{5}$, P.A. Vanrolleghem ${ }^{6}$
}

1 CH2M HILL, Inc., 4350 W. Cypress Street, Suite 600, Tampa, FL, 33607 USA, Corresponding Author (E-mail: jboltz@ch2m.com)

2 ETH Zürich, Hoenggerberg, HIL G31.3, Wolfgang-Pauli-Strassa 15, CH-8093 Zürich, Switzerland, and Eawag, Überlandstrasse 133, CH-8600 Dübendorf, Switzerland (E-mail: Eberhard.Morgenroth@eawag.ch)

3 INRA, Laboratoire de Biotechnologie de l'Environnement, Avenue des Etangs, Narbonne, F-11100, France (E-mail: brockman@supagro.inra.fr)

4 Hampton Roads Sanitation District, 1440 Air Rail, Ave., Virginia Beach, VA, 23455 USA

(E-mail: bott@hrsd.com)

5 Hazen and Sawyer, 11311 Cornell Park Dr., Cincinnati, OH, 45242 USA

(E-mail:jgellner@hazenandsawyer.com)

6 modelEAU, Université Laval, Pavillon Pouliot, Québec (QC), Canada G1K 7P4

(E-mail: Peter.Vanrolleghem@gci.ulaval.ca)

\begin{abstract}
Biofilm models are valuable tools for process engineers despite several uncertainties including the dynamics and rate of biofilm detachment, concentration gradients external to the biofilm surface, and undefined biofilm reactor model calibration protocol. The present investigation serves to (1) evaluate two ad hoc model calibration procedures, (2) systematically evaluate critical biofilm model assumptions and components, and (3) conduct a sensitivity analysis with the aim of identifying parameter subsets for biofilm reactor model calibration. AQUASIM was used to describe submerged-completely mixed combined carbon oxidation and nitrification IFAS and MBBR systems, and tertiary nitrification and denitrification MBBRs. The magnitude of model output dependency on uncertainties in model parameters was determined by means of a sensitivity analysis. The following conclusions were drawn from this work. Ad-hoc expert-based trial and error calibration may have limited applicability as resulting parameters are often not sufficiently general to predict system performance during other periods, even for the same wastewater treatment plant. At both temperatures simulated $\left(\mathrm{T}=20^{\circ} \mathrm{C}\right.$ and $\left.12^{\circ} \mathrm{C}\right)$, each system modeled was sensitive to changes in the biofilm parameter mass transfer boundary layer thickness $\left(\mathrm{L}_{\mathrm{L}}\right)$. Sensitivity of model predictions to kinetic and biofilm parameters is strongly influenced by temperature. A cold temperature local sensitivity analysis provided evidence that biofilm models are sensitive to changes in mass transfer boundary layer thickness $\left(\mathrm{L}_{\mathrm{L}}\right)$, diffusivity coefficient (D), maximum growth rate $(\mu)$, and affinity constant $(K)$ for the rate-limiting substrate. No simple recommendations for the more appropriate model calibration methodology can be suggested as sensitivity of model predictions significantly depends on environmental conditions (e.g., temperature) and treatment objectives (e.g., nitrification, denitrification).
\end{abstract}

\section{Keywords}

AQUASIM; biofilm; calibration; design; identifiably; model; nitrogen removal; parameter; wastewater

\section{INTRODUCTION}

Simulators incorporating one-dimensional (1-D) biofilm models are used in engineering practice. Boltz et al. (2010a) conducted a review of the wastewater treatment plant simulators listed in Table $\mathbf{1}$ for the purpose of comparing approaches to developing and implementing mathematical biofilm models as a basis for describing biofilm reactors. 
Table 1. Biofilm models used in practice (Boltz et al. 2010b)

\begin{tabular}{|c|c|c|c|}
\hline Software & Company & $\begin{array}{l}\text { Biofilm model type and } \\
\text { biomass distribution }\end{array}$ & Reference \\
\hline AQUASIM $^{\mathrm{TM}}$ & $\begin{array}{l}\text { EAWAG, Swiss Federal Institute of Aquatic } \\
\text { Science and Technology, } \\
\text { Dübendorf, Switzerland } \\
\text { (www.eawag.ch/index EN) }\end{array}$ & $\begin{array}{l}\text { 1-D, DY, N; } \\
\text { Heterogeneous }\end{array}$ & $\begin{array}{l}\text { Wanner and Reichert } \\
\text { (1996) (modified) }\end{array}$ \\
\hline AQUIFAS ${ }^{\mathrm{TM}}$ & $\begin{array}{l}\text { Aquaregen, } \\
\text { Mountain View, California } \\
\text { (www.aquifas.com) }\end{array}$ & $\begin{array}{l}\text { 1-D, } \\
\text { DY, SE and N, } \\
\text { Heterogeneous }\end{array}$ & $\begin{array}{l}\text { Sen and Randall } \\
\text { (2008) }\end{array}$ \\
\hline BioWin $^{\mathrm{TM}}$ & $\begin{array}{l}\text { EnviroSim Associates Ltd., } \\
\text { Flamborough, Canada } \\
\text { (www.envirosim.com) }\end{array}$ & $\begin{array}{l}\text { 1-D, DY, N, } \\
\text { Heterogeneous }\end{array}$ & $\begin{array}{l}\text { Wanner and Reichert } \\
\text { (1996) (modified), } \\
\text { Takács et al. (2007) }\end{array}$ \\
\hline GPS-XTM & $\begin{array}{l}\text { Hydromantis Inc., } \\
\text { Hamilton, Canada } \\
\text { (www.hydromantis.com) }\end{array}$ & $\begin{array}{l}\text { 1-D, DY, N, } \\
\text { Heterogeneous }\end{array}$ & Hydromantis (2006) \\
\hline Pro2D ${ }^{\mathrm{TM}}$ & $\begin{array}{l}\text { CH2M HILL Inc., } \\
\text { Englewood, Colorado } \\
\text { (www.ch2m.com/corporate) }\end{array}$ & $\begin{array}{l}\text { 1-D, SS, N(A), } \\
\text { Homogeneous } \\
\text { (constant } \mathrm{L}_{\mathrm{F}} \text { ) }\end{array}$ & Boltz et al. (2009) \\
\hline $\mathrm{Simba}^{\mathrm{TM}}$ & $\begin{array}{l}\text { ifak GmbH, } \\
\text { Magdeburg, Germany } \\
\text { (www.ifak-system.com) }\end{array}$ & $\begin{array}{l}\text { 1-D, DY, N, } \\
\text { Heterogeneous }\end{array}$ & $\begin{array}{l}\text { Wanner and Reichert } \\
\text { (1996) (modified) }\end{array}$ \\
\hline STOAT $^{\text {TM }}$ & $\begin{array}{l}\text { WRc, } \\
\text { Wiltshire, England } \\
\text { (www.wateronline.com/ } \\
\text { storefronts/wrcgroup.html) }\end{array}$ & $\begin{array}{l}\text { 1-D, DY, N, } \\
\text { Heterogeneous }\end{array}$ & $\begin{array}{l}\text { Wanner and Reichert } \\
\text { (1996) (modified) }\end{array}$ \\
\hline WEST $^{\mathrm{TM}}$ & $\begin{array}{l}\text { MOSTforWATER, } \\
\text { Kortrijk, Belgium } \\
\text { (www.mostforwater.com) }\end{array}$ & $\begin{array}{l}\text { 1-D, DY, N(A) }{ }^{\mathrm{a}}, \mathrm{N}^{\mathrm{b}}, \\
\text { Homogeneous }^{\mathrm{a}}, \\
\text { Heterogeneous }^{\mathrm{b}}\end{array}$ & $\begin{array}{l}\text { Rauch et al. }(1999)^{\mathrm{a}} \text {, } \\
\text { Wanner and Reichert } \\
(1996)\left(\text { modified) }{ }^{\mathrm{b}}\right.\end{array}$ \\
\hline
\end{tabular}

1-D = one dimensional, $\mathrm{DY}=$ dynamic. $\mathrm{N}=$ numerical, $\mathrm{N}(\mathrm{A})$ numerical solution using analytical flux expressions

The researchers identified several commonalities amongst the biofilm models in the simulators reviewed. For example, there was a unanimous assumption that the mathematical description of a 1$\mathrm{D}$ biofilm is sufficient for engineering practice. However, differences in modeling approaches also exist. Most notably the assumed biofilm biomass distribution in some of the simulators evaluated was homogeneous, but the majority assumed a heterogeneous biofilm (i.e., a continuum comprised of a user defined number of layers) (Figure 1).
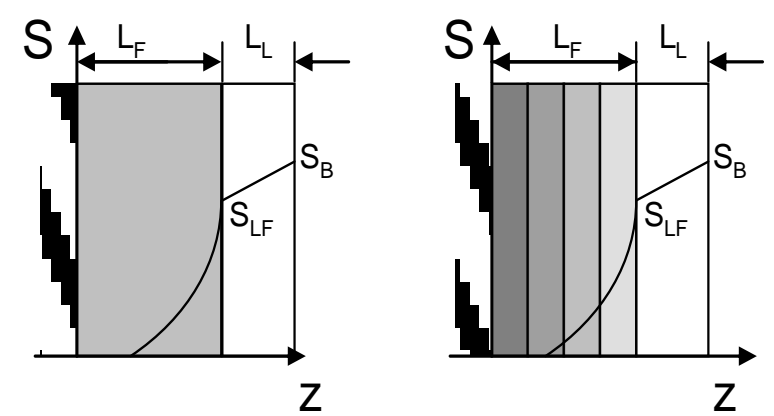

Figure 1. Schematic of a 1-D biofilm of thickness $L_{F}$ having an assumed homogeneous (left) and heterogeneous, or layered, (right) biomass distribution, MTBL of thickness $\mathrm{L}_{\mathrm{L}}$, and concentration profile decreasing from the bulk of the liquid $\left(S_{B}\right)$ to the liquid-biofilm interface $\left(S_{L F}\right)$.

The goal of this paper is to present (1) an evaluation of two ad hoc model calibration procedures, (2) a systematic evaluation of critical biofilm model assumptions and components, and (3) a sensitivity analysis with the aim of identifying parameter subsets for biofilm reactor model calibration. Boltz 
et al. (2010a) summarized the following items that cause uncertainty when using 1-D biofilm models to describe biofilm reactors: (1) the fate of particulate substrates, (2) biofilm distribution in the reactor and the effect biofilms have on reactor components, (3) dynamics and fate of biofilm detachment, (4) external mass transfer boundary layer thickness, and (5) a lack of biofilm reactor model calibration protocol. Parameter estimation and model calibration are serious concerns for process engineers who apply biofilm models in engineering practice. Therefore, parameters that are critical components of biofilm reactor models (that use a 1-D mathematical biofilm model) are introduced including attachment $\left(\mathrm{k}_{\mathrm{at}}\right)$ and detachment $\left(\mathrm{k}_{\mathrm{det}}\right)$ coefficients, mass transfer boundary layer thickness $(\mathrm{MTBL})$, rate-limiting diffusivity coefficient inside the biofilm ( $\mathrm{D}_{\mathrm{F} \text {,rate-limiting }}$ ), and the biokinetic parameters maximum growth rate $(\mu)$ and the rate-limiting substrate half-saturation coefficient $\left(\mathrm{K}_{\mathrm{i}, \text { rate-limiting }}\right)$. Finally, the calibration of biofilm reactor models is discussed.

\section{MODEL FEATURES}

\section{Attachment and detachment process kinetics and rate coefficients}

An accurate mathematical description of particle attachment and detachment processes is a critical component of biofilm reactor models. Unfortunately, attachment/detachment process mechanics are poorly understood. Conceptually, particles suspended in the bulk liquid are hydrodynamically transported to the vicinity of the biofilm. From the bulk phase, particles are subjected to concentration gradients external to the biofilm surface. Particles enter the biofilm matrix through channels, crevasses, and other structural irregularities where they attach to the biofilm surface (see Reichert and Wanner (1997) for a description of particle transport within the biofilm matrix). Once entrapped, the particles can be hydrolyzed by extracellular polymeric enzymes. The hydrolyzed particles result in soluble substrate that diffuses into the biofilm where well known biochemical transformation processes yield biomass. Alternatively, particles that have attached to the biofilm surface from the bulk phase remain unchanged and exit the system after detaching from the biofilm matrix. Most of the heterogeneous 1-D biofilm models listed in Table 1 describe the rate of particle attachment $\left(\mathrm{r}_{\mathrm{at}}\right)$ as a first-order process

$$
r_{a t}=k_{a t} \cdot X_{T S S, b u l k}
$$

dependent on an attachment rate coefficient $\left(\mathrm{k}_{\mathrm{at}}\right)$ and the bulk-liquid particle concentration. Boltz and La Motta (2007) presented a model describing variability in this parameter with influent particle concentrations. The researchers postulated that increasing particle concentrations ultimately reduced the biofilm surface area available for particle attachment; thereby, the particle attachment coefficient decreases until reaching a plateau. The plateau was considered commensurate with a condition in which a minimum biofilm area was consistently available as a result of continuously detaching biofilm fragments (during steady operating conditions - variable hydrodynamics can influence biofilm structure). Given the current state of the science, experimental data is required to develop/validate or evaluate existing approaches to simulating the fate of particles in biofilm reactors.

Steady-state biofilm models have assumed a constant biofilm thickness in which case biofilm growth is either balanced by internal loss (e.g., decay and hydrolysis, or endogenous respiration) or by detachment. This approach has been successfully applied to simulate biofilm reactors at steady state, but their dynamic simulation requires that a detachment model is included despite rather limited mechanistic understanding. The rate (Morgenroth and Wilderer 2000; Boltz et al. 2010a) and category (i.e., abrasion, erosion, sloughing and predator grazing) of detachment can have a 
significant influence on biofilm reactor simulation and performance (Morgenroth 2003). Kissel et al. (1984) stated that problems inherent to biofilm detachment modeling include a poor understanding of fundamental (biofilm detachment) process mechanics and the inability to predict exactly at what location inside the biofilm detachment will occur. Detachment location is important when taking into account a heterogeneous biofilm distribution throughout the reactor either by combining multiple 1-D simulations or by 2- or 3-D modeling (Morgenroth et al., 2000). Unlike attachment, Boltz et al. (2010a) described seven different biofilm detachment rate expressions $\left(\mathrm{r}_{\mathrm{det}}\right)$ for the heterogeneous 1-D biofilm models listed in Table 1. Detachment rate equations can be categorized according to the aspect controlling detachment: biofilm thickness $\left(\mathrm{L}_{\mathrm{F}}\right)$, shear, or growth/activity. Mixed-culture biofilms, such as those growing in a combined carbon oxidation and nitrification MBBR, are subject to competition for substrate between fast-growing heterotrophic and slow-growing autotrophic organisms (primarily for dissolved oxygen). Morgenroth and Wilderer (2000) performed a modeling study that demonstrated the ammonium flux was significantly influenced by the mode of detachment. Essentially, biofilm (thickness) dynamics influenced competition for substrate between heterotrophic and autotrophic organisms; high variations in biofilm thickness dynamics favored the faster growing heterotrophic organisms. To assess this impact, two functions describing the rate of detachment are evaluated in this paper, and model results are compared with output from a model having user defined (fixed) biofilm thickness that assumes a mass transfer, not biomass, limited biofilm.

\section{Concentration gradients external to the biofilm surface and the mass transfer boundary layer}

Biofilms growing in virtually all full-scale biofilm reactors are subject to some degree of substrate concentration gradients external to the biofilm surface. Concentration gradients external to the biofilm surface are not explicitly simulated in 1-D biofilm models. Rather, the reduction in concentration of any substrate is modeled as a mass-transfer resistance, $\mathrm{R}_{\mathrm{L}}\left(=\mathrm{L}_{\mathrm{L}} / \mathrm{D}_{\mathrm{aq}}\right)$. Based on the observation that the external mass-transfer resistance, $\mathrm{R}_{\mathrm{L}}$, is more dependent on biofilm reactor bulk-liquid hydrodynamics than biofilm thickness or surface heterogeneity, the impact of $R_{L}$ can be accounted for explicitly by empirical correlations (Wanner et al. 2006 - see Table A4 in the Appendix). However, a realistic description of hydrodynamic effects is ultimately dependent on an accurate estimate of the mass transfer boundary layer (MTBL) of thickness $\mathrm{L}_{\mathrm{L}}$. Therefore, the mass transfer boundary layer thickness is an important facet of biofilm-reactor models that use a 1-D biofilm model. The mass transfer boundary layer thickness may have a substantial impact on biofilm-reactor model results and therefore process design. However, factors influencing the biofilm model-reactor scale interface are not well understood. To quantify the impact of changes in $\mathrm{L}_{\mathrm{L}}$ three MTBL thicknesses are modeled: $100 \mu \mathrm{m}, 0 \mu \mathrm{m}$, and $\mathrm{L}_{\mathrm{L}}=\mathrm{L}_{\mathrm{c}} / \mathrm{Sh}$. Here, $\mathrm{L}_{\mathrm{c}}$ is the characteristic length and $\mathrm{Sh}$ is the Sherwood number.

\section{Diffusivity coefficient for the rate-limiting substrate inside the biofilm}

Soluble substrates are transported into biofilms by a combination of advection and diffusion. Generally, the most important mechanism is molecular diffusion (Zhang and Bishop, 1994). The largest component of biofilm is water, but the diffusivity of a solute inside the biofilm is generally less than that in water because of the tortuosity of the pores and minimal biofilm permeability. Consequently, an effective diffusivity must be applied. Many biofilm reactor models treat this value as $80 \%$ of the diffusivity in water (i.e., $\mathrm{D}=\mathrm{D}_{\mathrm{F}} / 0.8$ ) (Stewart, 2003). However, it has been demonstrated that the effective diffusion coefficient $\left(\mathrm{D}_{\mathrm{F}, \mathrm{i}}\right)$ for any soluble substrate $\mathrm{i}$ can vary with depth inside the biofilm (Beyenal and Lewandowski, 2000). The effective diffusivity decreases with depth because of increasing density and decreasing porosity and permeability of the biofilm with depth. 
Flow velocity past the biofilm is a major controlling factor determining biofilm density. Varying liquid velocity in the vicinity of the biofilm surface can influence a soluble substrate effective diffusivity inside a biofilm. Consequently, the varying flow rate can affect the rate of internal mass transfer and transformation rates (Bishop 2003). Turbulent, high-shear stress environments result in planar and denser biofilms while quiescent, low-shear stress environments will result in rough and less dense biofilms (van Loosdrecht et al. 1995). Picioreanu (1999) defined a growth number $\left(\mathrm{G}=\mathrm{L}_{\mathrm{F}}^{2} \cdot \mu_{\text {max }} \cdot \mathrm{X}_{\mathrm{F}} /\left(\mathrm{D}_{\mathrm{F}} \cdot \mathrm{S}_{\mathrm{B}}\right)\right)$ that can be related to biofilm roughness. Variables are defined in the Appendices. According to Picioreanu (1999), the biofilm may have a dense solid matrix and a flat surface when $G<5$. However, if $G>10$ the biofilm may develop complex structures such as mushroom clusters and streamers.

\section{Parameters: estimation and variable coefficients}

A parameter is an arbitrary constant whose value characterizes a system member. Biokinetic parameter estimation is a serious concern for practitioners who seek to use biofilm models for biofilm reactor process design because most parameter values can not be measured directly in fullscale municipal wastewater treatment plants (Brockmann et al., 2008). Parameters exist for every aspect of biofilm models including stoichiometry, kinetics, mass transfer and the biofilm itself. Stoichiometric parameter values and definitions are listed in Table A2 in the Appendix, kinetic parameter values and definitions are listed in Table A3 in the Appendix, and mass transfer and biofilm parameter values and definitions are listed in Table A4 in the Appendix for the model applied to this investigation. A majority of parameter values in modern process models (e.g., those described by Henze et al., 2000) have a substantial database that serves to define a relatively narrow range of values that are applicable to a majority of municipal wastewater treatment systems (see Hauduc et al. 2010). Existing biofilm models are relatively insensitive to changes in a majority of the biokinetic parameter values described by Henze et al. (2000) within a range of values reported in the literature except for, as an example, the autotrophic nitrifier maximum growth rate $(\mu)$. However, the mathematical description of some processes consists of variables, or lumped, parameters. These parameter values are often system specific and subject to significant uncertainty. The lumped parameters account for an incomplete mechanistic description of the simulated process. Lumped parameters in the biofilm model described in this paper include:

- $\quad$ oxygen affinity constant for autotrophic nitrifiers $\left(\mathrm{K}_{\mathrm{O} 2, \mathrm{~A}}\right)$

- endogenous respiration rate constants $\left(b_{\text {res }}\right)$

- $\quad$ attachment rate coefficient $\left(\mathrm{k}_{\mathrm{at}}\right)$

- detachment rate coefficient $\left(\mathrm{k}_{\mathrm{det}}\right)$

- mass transfer boundary layer thickness $\left(\mathrm{L}_{\mathrm{L}}\right)$

- ratio of diffusion in biofilm to diffusion in water $\left(\mathrm{D}_{\mathrm{F}} / \mathrm{D}\right)$

Identifying parameter subsets that require definition for biofilm model calibration has been the subject of recent investigations by Smets et al. (1999), Van Hulle et al. (2004), and Brockmann et al. (2008). Defining a reliable parameter subset(s) that requires definition for accurate model calibration must be established for systems commonly simulated in engineering practice. The subset selected will depend on the system studied.

\section{Calibration protocol}

Application of a dynamic biofilm model to describe full-scale municipal wastewater treatment processes requires a calibration of the selected model. Ad hoc expert-based trial and error and 
standardized systematic approaches have been used to calibrate process models. Sin et al. (2005) presented a critical comparison of systematic calibration protocols for activated sludge models. These protocols have many similarities that are applicable to biofilm reactor models including goal definition, data collection/verification/reconciliation, and validation. The major differences between the protocols reported by Sin et al. (2005) are related to the measurement campaign, experimental methods for influent wastewater characterization, and parameter subset selection and calibration. The major differences speak to areas of systematic calibration protocols for activated sludge models that will almost certainly be exasperated when creating a systematic protocol for calibrating a biofilm reactor model. Certainly, additional tests will be required to characterize the physical attributes of the suspended growth and biofilm compartments, and mathematical biofilm models have more parameters than activated sludge models. Furthermore, the biofilm compartment parameters must be estimated from bulk-phase measurements in order to have a timely and cost effective systematic approach to a calibrating protocol for a biofilm model.

Sin et al. (2008) reported the calibration of a dynamic biologically active (continuously backwashing) filter model using "traditional expert-based manual trial and error". The researchers manipulated system specific parameters related to attachment, detachment, and biofilm thickness. After calibration, Sin et al. (2008) successfully tested the calibrated model for another period. Similarly, Bilyk et al. (2008) reported the calibration of a denitrification filter model by adjusting "assumed biofilm thickness" and incorporating the assimilative denitrification reaction. Both of these biofilm reactor model calibration efforts were based on bulk-phase measurements, but only Sin et al. (2008) utilized measured characteristics of the biofilm. Such adjustments to systemspecific biofilm and biokinetic parameters in order to match observed data may not produce a properly calibrated model that is capable of describing a variety of design conditions for a WWTP. As previously discussed, the attachment coefficient, for example, has been experimentally demonstrated (and described mathematically) to change as a function of particle (total suspended solids) load (Boltz and La Motta, 2007). Then, it may be argued that adjusting the attachment coefficient (during "calibration") to match an observed data set would naturally render the "calibrated" model incapable of describing a different scenario (i.e., a wastewater treatment plant operational condition with a different particle load). This would be identified during when testing the calibrated model. Suffice it to say that a reliable and transparent description of recommended approaches for the application and calibration of biofilm models are required for the models to gain general acceptance, understanding, and become effectively used in engineering design. Protocol defining methodology for sampling, testing, evaluating and applying data to mathematical biofilm reactor models is required. It is likely that existing biofilm reactor models will require improvement for reliable dynamic simulation in practice.

\section{MATERIAL AND METHODS}

Two models were used in this study. An integrated fixed-film activated sludge module in the BioWin ${ }^{\mathrm{TM}}$ simulator (file version 3.01.802; Takács et al. 2007) was used to evaluate two ad hoc expert-based trial and error biofilm model calibration techniques. All other modeling studies were carried out using AQUASIM (Reichert 1998). Biofilm models have been applied as they exist in AQUASIM, and do not represent the 1-D biofilm models coded for implementation in any of the simulators reviewed by Boltz et al. (2010a).

\section{Ad hoc expert-based trial and error calibration}

The City of Greensboro, North Carolina, USA, owns and operates the T.Z. Osborne Water Reclamation Facility (WRF). One train in the full-scale secondary treatment system (i.e., bioreactor 
and clarifier) was converted to a demonstration-scale integrated fixed-film activated sludge process capable of treating $13,250 \mathrm{~m}^{3} \mathrm{~d}^{-1}$ of primary (clarifier) effluent. Each bioreactor consisted of 12 cells. The first three cells, which were labeled A, B, and C, had a total volume of $1,250 \mathrm{~m}^{3}$. The following six aerobic cells, which were labeled D - I, were separated by a submerged baffle and had a total volume of $5,000 \mathrm{~m}^{3}$. Three of the nine bioreactor cells were converted to aerobic integrated fixed-film activated sludge cells containing 37-percent plastic biofilm carrier fill. The plastic biofilm carriers have a $185 \mathrm{~m}^{2} \mathrm{~m}^{-3}$ effective specific surface area at the design media fill. The IFAS cells were labeled D, E, and F. A $4.0 \mathrm{~g} \mathrm{~m}^{-3}$ bulk-liquid dissolved oxygen concentration was maintained with aeration (based on an average in situ measurement recorded in cells D and F). The system was operated for approximately one year (i.e., April 2008 until April 2009) for the purpose of verifying process design and identifying significant process-mechanical related issues. Data was gathered at multiple locations and for multiple process parameters including (1) flow, (2) nitrogen, phosphorus, and organic matter influent and effluent concentrations, and (3) attached and suspended phase suspended solids. See McGehee et al. (2009) for additional information. Figure 2 presents the T.Z. Osborne WRF process flow diagram.

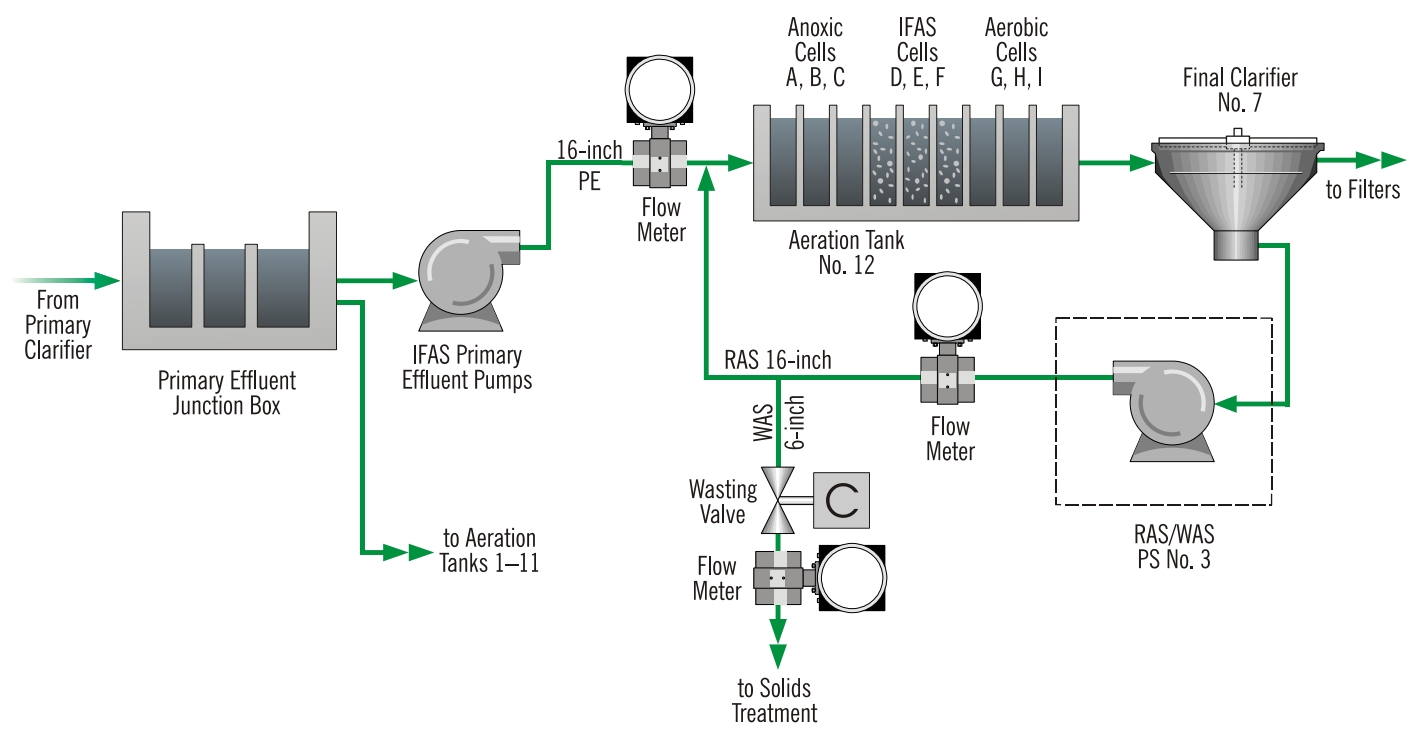

Figure 2. T.Z. Osborne Water Reclamation Facility process flow diagram

\section{Kinetic model}

State variables considered for the modeling studies carried out in AQUASIM ${ }^{\mathrm{TM}}$ consist of soluble (S) and particulate $(\mathrm{X})$ matter. The state variables and biochemical transformation processes (and rate expressions) included in the benchmark study are similar to those described by Henze et al. (2000) for ordinary heterotrophic and autotrophic organisms in ASM3. The ASM3 model was used, but without modeling storage. In addition, for models describing tertiary denitrification, aerobic and anoxic growth and endogenous respiration of two types of methanol degraders $\left(\mathrm{X}_{\mathrm{M} 1}\right.$ and $\left.\mathrm{X}_{\mathrm{M} 2}\right)$ were included in the model. A complete list of state variables, stoichiometric parameters, kinetic parameters, biofilm parameters, and transformation rate expressions are listed in Tables A1, A2, A3, A4, and A5 in the Appendix, respectively. 


\section{Benchmark simulations}

Municipal wastewater treatment scenarios that are commonly the subject of full-scale process design and evaluation are modeled: combined carbon oxidation and nitrification, and tertiary nitrification and denitrification. The submerged and completely mixed biofilm reactors are described as continuous flow stirred tank reactors (CFSTRs) analogous to moving bed biofilm reactors (MBBRs). In addition, an integrated fixed film activated sludge (IFAS) process for combined carbon oxidation and nitrification was modeled. Influent wastewater characteristics are defined in Table 2. The influent wastewater characteristics were developed based on selected references and authors' experience with the simulation and design of these processes. The influent wastewater flow rate for each case modeled was $35,000 \mathrm{~m}^{3} / \mathrm{d}$. Reactor configurations were defined based on (1) German design criteria describing submerged fixed-bed reactors (ATV, 2002) applied to a combined carbon oxidation and nitrification MBBR and a tertiary nitrification MBBR, and (2) a residual methanol concentration requirement less than $1 \mathrm{mg} \mathrm{COD} / \mathrm{L}$ remaining in the tertiary denitrification MBBR effluent stream. Integrated fixed-film activated sludge process design is evolving; therefore, generally accepted design criteria do not exist. Therefore, the IFAS system configuration was created based on author experience, which has been presented to a certain extent by Kim et al. (2010). Simulations were run for $20^{\circ} \mathrm{C}$ unless otherwise stated. AQUASIM was used to execute the benchmark simulations such that changes in the one-dimensional biofilm model (e.g., assumed homogeneous or heterogeneous biofilm biomass distribution) were systematically evaluated. The different modeling scenarios are summarized in Table 3.

Table 2. Reactor configurations and wastewater characteristics for the simulated municipal wastewater treatment scenarios

\begin{tabular}{lcccc}
\hline & $\begin{array}{c}\text { IFAS } \\
\text { Combined carbon } \\
\text { oxidation and } \\
\text { nitrification }\end{array}$ & $\begin{array}{c}\text { MBBR } \\
\text { Combined carbon } \\
\text { oxidation and } \\
\text { nitrification }\end{array}$ & $\begin{array}{c}\text { MBBR } \\
\text { Tertiary nitrification }\end{array}$ & $\begin{array}{c}\text { MBBR } \\
\text { Tertiary } \\
\text { denitrification }\end{array}$ \\
\hline Reactor configuration & 2,200 & 5,000 & 2,200 & 1,400 \\
Reactor volume $\left[\mathrm{m}^{3}\right]$ & 550,000 & $1,250,000$ & 550,000 & 350,000 \\
Biofilm surface area $\left[\mathrm{m}^{2}\right]$ & 4.0 & 4.0 & 5.0 & 0.0 \\
bulk DO $\left[\mathrm{mg} \mathrm{O}_{2} / \mathrm{L}\right]$ & 35,000 & 35,000 & 35,000 & 35,000 \\
Influent flow rate $\left[\mathrm{m}^{3} / \mathrm{d}\right]$ & 40.0 & & & 1.1 \\
Wastewater characteristics & - & 89.0 & 5.7 & 15.0 \\
$\mathrm{~S}_{\mathrm{S}}\left[\mathrm{g} \mathrm{COD} / \mathrm{m}^{3}\right]$ & 13.3 & - & - & 18.7 \\
$\mathrm{~S}_{\mathrm{M}}\left[\mathrm{g} \mathrm{COD} / \mathrm{m}^{3}\right]$ & 26.0 & 13.3 & 18.7 & 2.0 \\
$\mathrm{~S}_{\mathrm{I}}\left[\mathrm{g} \mathrm{COD} / \mathrm{m}^{3}\right]$ & 0.7 & 26.0 & 22.5 & 5.1 \\
$\mathrm{~S}_{\mathrm{NH} 4}\left[\mathrm{~g} \mathrm{~N} / \mathrm{m}^{3}\right]$ & 4.8 & 0.7 & 1.4 & 4.1 \\
$\mathrm{~S}_{\mathrm{NO} 3}\left[\mathrm{~g} \mathrm{~N} / \mathrm{m}^{3}\right]$ & 250.0 & 4.8 & 5.0 & 8.3 \\
$\mathrm{~S}_{\mathrm{ALK}}\left[\mathrm{mole} \mathrm{HCO}_{3}{ }^{-} / \mathrm{m}^{3}\right]$ & 69.3 & 250.0 & 0.2 & 2.1 \\
$\mathrm{X}_{\mathrm{S}}\left[\mathrm{g} \mathrm{COD} / \mathrm{m}^{3}\right]$ & 69.3 & 2.1 & \\
$\mathrm{X}_{\mathrm{I}}\left[\mathrm{g} \mathrm{COD} / \mathrm{m}^{3}\right]$ & & & & \\
\hline
\end{tabular}


Table 3. Modeling scenarios (base scenario settings are underlined).

\begin{tabular}{lllll}
\hline Scenario & Parameter & & \multicolumn{2}{c}{ Values evaluated } \\
\hline I & Biofilm thickness, $\mathrm{L}_{\mathrm{F}}$ & $\underline{\text { Fixed thickness }(200 \mu \mathrm{m})}$ & Deep biofilm $(2,000 \mu \mathrm{m})$ & $\begin{array}{l}\mathrm{L}_{\mathrm{F}} \text { resulting from different } \\
\text { detachment rate functions }\end{array}$ \\
II & Biofilm structure & $\underline{\text { Heterogeneous (layered })}$ & Homogeneous & \\
III & MTBL thickness, $\mathrm{L}_{\mathrm{L}}$ & $\underline{\mathrm{L}_{\mathrm{L}}=100 \mu \mathrm{m}}$ & $\mathrm{L}_{\mathrm{L}}=0 \mu \mathrm{m}$ & $\mathrm{L}_{\mathrm{L}}=\mathrm{L}_{\mathrm{c}} / \mathrm{Sh}^{(*)}$ \\
IV & Reactors-in-series & $\underline{\mathrm{N}=1}$ & $\mathrm{~N}=3$ & $\mathrm{~N}=6$ \\
V & Temperature & $\underline{20^{\circ} \mathrm{C}}$ & $12^{\circ} \mathrm{C}$ & \\
VI & Parameter values & From Table 9A in the Appendix &
\end{tabular}

(*) Mass transfer boundary layer thickness $\mathrm{L}_{\mathrm{L}}$ calculated for each soluble substance individually (see Appendix A4)

Biofilm detachment was simulated to achieve a constant biofilm thickness either by a-priori selecting a biofilm thickness or, in one of the cases in Scenario I, by a-priori selecting the value of the detachment rate coefficient. Thereby, a constant biofilm thickness $L_{F}$ was maintained. The detachment rate may vary as a result of the assumed biofilm biomass distributions since the rate of growth and endogenous respiration is dependent on local substrate availability and environmental conditions. Biofilm fragments were assumed to detach from the biofilm surface in which case preferential detachment is considered for heterogeneous (layered) biofilms biomass distribution (i.e., bacteria growing in the biofilm-water interface layer detach and enter the bulk of the liquid).

\section{Sensitivity analysis}

Model sensitivity to changes in biokinetic and biofilm parameter values were evaluated for steady state and discussed with emphasis given to identifying the parameters that may have a negligible impact on model results when the values are adjusted within a range reported in the literature. Parameter values that may vary from system to system treating municipal wastewater (e.g., $\mathrm{K}_{\mathrm{O} 2, \mathrm{~A}}$, $\mathrm{L}_{\mathrm{F}}$ ) are identified and the impact of changes in their values (within a range of values reported in the literature) are evaluated. Although parameter values may vary considerably, model sensitivity was not evaluated based on a global sensitivity analysis as described in Brockmann et al. (2008), but on a simpler local sensitivity analysis. While the global sensitivity analysis accounts for non-linear model outcomes within the defined uncertainty ranges of the parameters, the local sensitivity analysis linearly extrapolates the impact of a small change in the parameter value to the uncertainty range of the parameter. Local sensitivity analyses were carried out for the base scenario altering the parameters by $1 \%$ of their default parameter value. A sensitivity measure $\delta$ was calculated from scaled sensitivity values that include information on a reasonable range (uncertainty range) of the parameters (Brun et al., 2001):

$$
\delta=\sqrt{\frac{1}{n} \sum_{i=1}^{n} s_{i, j}^{2}} \quad \text { with } \quad s_{i, j}=\frac{\Delta p_{j}}{s c_{i}} \cdot \frac{\partial y_{i}}{\partial p_{j}}
$$

where $\Delta p_{j}$ represents the uncertainty range of the parameter $p_{j}, s c_{i}$ is a scale factor, and $n$ is the number of model outputs considered. A large $\delta$ means that a change of $\Delta p_{j}$ in parameter $p_{j}$ has a large impact on the considered model output(s). Model parameters were assigned to three uncertainty classes according to Brun et al. (2002). In this study, sensitivity analyses were only carried out for parameters from uncertainty classes 2 and 3. Parameters from uncertainty class 1 were not considered for sensitivity analysis due to their low uncertainty $(5 \%$ of the default parameter value) compared to uncertainty classes 2 and 3 . The uncertainty range of parameters from 
uncertainty class 2 is $20 \%$ of the default parameter value, and $50 \%$ for parameters from uncertainty class 3. All studied parameters and their uncertainty ranges are given in Appendix A. Key differences between the one-dimensional models are described for each municipal wastewater treatment scenario and are used to make inferences about the type of information that is required to calibrate a biofilm reactor model.

\section{RESULTS AND DISCUSSION}

Mathematical modeling of biofilms was evaluated first by attempting to calibrate a model (that exists in the simulator BioWin ${ }^{\mathrm{TM}}$ ) to existing data for a full-scale IFAS plant. Subsequently, a systematic evaluation of critical parameters in biofilm modeling and biofilm model calibration was performed.

\section{Ad hoc expert-based trial and error model calibration describing a full-scale IFAS process}

A biofilm reactor model that is based on the mathematical description of a one-dimensional biofilm was applied to describe a full-scale wastewater treatment plant that has implemented the IFAS process for combined carbon oxidation and nitrification in a secondary process (BioWin ${ }^{\mathrm{TM}}$, cursory description of the process model in Table 1). Simple methods for calibration that are analogous to approaches used by practitioners when calibrating suspended growth models (in simulators) were applied to the IFAS model described here. Since three separate IFAS cells were operated in series, each of the cells was subjected to different organic matter and nitrogen loadings during the demonstration project. A biological wastewater simulation model was calibrated using two different methodologies for calibration. First, attachment and detachment rates were varied locally for each reactor to match suspended and fixed phase solids (the so-called attached/detachment matching approach). Second, adjustment was made to the maximum density of specific microorganisms within the biofilm (the so-called variation of maximum biofilm population densities approach). Adjustments were made to the biomass concentrations in each cell. Two different periods with different loading conditions were considered for the calibration of the model. A summary of pilot operating conditions during those two periods are summarized in Table 4. The two selected time periods differ in terms of wastewater flow, organic and nitrogen loadings onto the IFAS cells and operating conditions such as dissolved oxygen concentrations and temperature. Comparison of solids in the suspended and biofilm using the attachment/detachment method of calibration is shown in Table 5 for each time period considered.

Table 4. Average bulk-liquid dissolved oxygen concentration, mixed liquor suspended solids concentration, unit biofilm biomass, and solids residence time for selected periods

\begin{tabular}{lcc}
\hline & $10,600 \mathrm{~m}^{3} \mathrm{~d}^{-1}$ & $13,250 \mathrm{~m}^{3} \mathrm{~d}^{-1}$ \\
Parameter & $07 / 09 / 2008-9 / 17 / 2008$ & $10 / 08 / 2008-12 / 17 / 2008$ \\
\hline DO $(\mathrm{mg} / \mathrm{L})$ - IFAS_D & 3.9 & 2.4 \\
DO $(\mathrm{mg} / \mathrm{L})$ - IFAS_E & 4.7 & 2.6 \\
DO $(\mathrm{mg} / \mathrm{L})$ - IFAS_F & 5.0 & 5.3 \\
Temperature $\left({ }^{\circ} \mathrm{C}\right)$ & 28.3 & 23.4 \\
MLSS $(\mathrm{mg} / \mathrm{L})$ & 2,080 & 2,070 \\
Biofilm Biomass $\left(\mathrm{g}_{\text {TSS }} / \mathrm{m}^{2}\right)$ - IFAS_D & 14.7 & 14.6 \\
Biofilm Biomass $\left(\mathrm{g}_{\text {TSS }} / \mathrm{m}^{2}\right)$ - IFAS_E & 7.3 & 14.3 \\
Biofilm Biomass $\left(\mathrm{g}_{\text {TSS }} / \mathrm{m}^{2}\right)$ - IFAS_F & 4.2 & 8.6 \\
Avg Biofilm Biomass $\left(\mathrm{g}_{\text {TSS }} / \mathrm{m}^{2}\right)$ & 8.7 & 12.5 \\
Aerobic SRT (days) & 5.8 & 7.8 \\
Aerobic Suspended Biomass SRT (days) & 3.5 & 4.7 \\
Total SRT (days) & 6.9 & 8.9 \\
\hline \hline
\end{tabular}


Table 5. Attachment-Detachment ad hoc approach to calibrate a model

\begin{tabular}{lcccccc}
\hline & \multicolumn{2}{c}{$07 / 09 / 2008-9 / 17 / 2008$} & \multicolumn{3}{c}{$10 / 08 / 2008-12 / 17 / 2008$} \\
Parameter & Model & Actual & $\%$ Diff. & Model & Actual & $\%$ Diff. \\
\hline MLSS $(\mathrm{mg} / \mathrm{L})$ & 2,073 & 2,078 & $0.21 \%$ & 2,071 & 2,069 & $0.11 \%$ \\
IFAS D $\left(\mathrm{g}_{\mathrm{TSS}} / \mathrm{m}^{2}\right)$ & 14.67 & 14.70 & $0.18 \%$ & 14.59 & 14.64 & $0.37 \%$ \\
IFAS E $\left(\mathrm{g}_{\mathrm{TSS}} / \mathrm{m}^{2}\right)$ & 7.37 & 7.32 & $0.70 \%$ & 14.30 & 14.34 & $0.28 \%$ \\
IFAS F $\left(\mathrm{g}_{\mathrm{TSS}} / \mathrm{m}^{2}\right)$ & 4.20 & 4.19 & $0.16 \%$ & 8.88 & 8.61 & $3.01 \%$ \\
Biofilm Biomass $\left(\mathrm{g}_{\text {TSS }} / \mathrm{m}^{2}\right)$ & 8.75 & 8.74 & $0.12 \%$ & 12.59 & 12.53 & $0.45 \%$ \\
\hline
\end{tabular}

In order to evaluate the ability of the model to predict biofilm solids and system performance under differing conditions, the calibrated model from each period was applied to operating conditions for the other (i.e. calibrated model from the $13,250 \mathrm{~m}^{3} \mathrm{~d}^{-1}$ period was applied to the $10,600 \mathrm{~m}^{3} \mathrm{~d}^{-1}$ period). The initial difference between the predicted solids in the suspended and fixed phases for each case was significant as shown in Table 6.

Table 6. Attachment and Detachment Rates - Calibration and Prediction

\begin{tabular}{lcccccc}
\hline Parameter & Model & Actual & $\%$ Diff. & Model & Actual & $\%$ Diff. \\
\hline & \multicolumn{4}{c}{ Application of $13,250 \mathrm{~m}^{3} \mathrm{~d}^{-1}$} & \multicolumn{2}{c}{ Application of $10,600 \mathrm{~m}^{3} \mathrm{~d}^{-1}$} \\
& calibrated model to $10,600 \mathrm{~m}^{3} \mathrm{~d}^{-1}$ & condition & calibrated model to $13,250 \mathrm{~m}^{3} \mathrm{~d}^{-1}$ condition \\
MLSS $(\mathrm{mg} / \mathrm{L})$ & 1,674 & 2,078 & $21.50 \%$ & 2,520 & 2,069 & $19.66 \%$ \\
IFAS D $\left(\mathrm{g}_{\text {TSS }} / \mathrm{m}^{2}\right)$ & 15.00 & 14.70 & $2.07 \%$ & 15.13 & 14.64 & $3.25 \%$ \\
IFAS E $\left(\mathrm{g}_{\text {TsS }} / \mathrm{m}^{2}\right)$ & 14.20 & 7.32 & $63.91 \%$ & 7.62 & 14.34 & $61.25 \%$ \\
IFAS F $\left(\mathrm{g}_{\text {TSS }} / \mathrm{m}^{2}\right)$ & 7.92 & 4.19 & $61.47 \%$ & 4.71 & 8.61 & $58.67 \%$ \\
Biofilm Biomass $\left(\mathrm{g}_{\text {TSS }} / \mathrm{m}^{2}\right)$ & 12.37 & 8.74 & $34.44 \%$ & 9.15 & 12.53 & $31.20 \%$ \\
\hline
\end{tabular}

Because higher fixed phase solids were present in the $13,250-\mathrm{m}^{3} \mathrm{~d}^{-1}$ calibration period, a lower MLSS than actual was predicted when these factors were applied to the $10,600-\mathrm{m}^{3} \mathrm{~d}^{-1}$ case. Conversely, application of the $10,600-\mathrm{m}^{3} \mathrm{~d}^{-1}$ period calibration to the $13,250-\mathrm{m}^{3} \mathrm{~d}^{-1}$ period over predicted suspended phase biomass. Generally, the offset of predicted biomass in the suspended phase was reflected by the difference in fixed phase biomass (i.e. similar total solids in the system, but different predicted location of the biomass). Predicted performance in the reactors was not affected, suggesting that the amount of total solids predicted in the reactors was similar. Results were similar when local biofilm density model parameters were used for calibration to the measured pilot plant solids.

The calibration in this example was based on mixed liquor and biofilm suspended solids, and bulkliquid nitrogenous compound $(\mathrm{N})$, phosphorus $(\mathrm{P})$, and chemical oxygen demand (COD) concentrations. Challenges in modeling an IFAS process are related to suspended growth and biofilm interactions, and their response to changes in loading and operational conditions that alter the biofilm composition. Calibration using the two methods discussed was based on matching N, P, and COD concentration profiles and (suspended growth and biofilm) solids concentrations observed in the full-scale reactors. Because each calibration method was specifically to the biofilm and suspended phase solids concentrations and only involved adjustment of a single parameter, the complex influences on biofilm formation, maintenance, and process performance were not effectively calibrated to actual operating conditions. 
This example illustrates several key considerations in the use of biofilm models for engineering design. From a biofilm parameter estimation perspective, the evaluation performed on this project only considered biofilm solids as the means of calibrating the system. There are other factors that could be adjusted to more closely simulate solids and performance (e.g., $\mathrm{L}_{\mathrm{L}}, \mathrm{D}_{\mathrm{F}}$ ). A variety of information was available for this calibration exercise, and such information is likely to approach the practical limit of data available to process engineers who seek to model full-scale biofilm reactors. In many cases, reliance on generally applicable empirical data, in conjunction with mathematical biofilm models, is still necessary to model an IFAS or biofilm reactor.

At present, there has been no information describing the relationship between reactor-scale conditions in full-scale wastewater treatment plants and the biofilm being mechanistically described with one-dimensional biofilm models. For instance, attachment/detachment of biofilm solids are related to a host of reactor-scale operating conditions including, but not limited to, aeration, mixing intensity, and the suspended phase solids concentration. In order for biofilm models to be used, these relationships should be established.

\section{Benchmark simulations}

Different modeling scenarios were evaluated based on the concentration (remaining in the effluent stream) of each state variable and soluble substrate fluxes through the biofilm surface. In Table 7 , results are presented for a combined carbon oxidation and nitrification MBBR model, Table 8 describes results from a tertiary nitrification MBBR model, Table $\mathbf{9}$ describes results from a tertiary denitrification MBBR model, and Table 10 describes results from an IFAS model. The processes have been described previously (see Table 2). The biofilm thickness (Scenario I described in Table 3) had an impact on the occurrence of denitrification in the biofilm and the extent of hydrolysis. Denitrification and hydrolysis rates were higher in thicker biofilms $(2,000 \mu \mathrm{m})$ whereas combined carbon oxidation and nitrification was higher in thinner biofilms $(200 \mu \mathrm{m})$. Therefore, if denitrification is desired the biofilm reactor should be operated in a manner that promotes the development of thicker biofilms. In contrast, if low organic carbon and ammonium concentrations remaining in the effluent stream are desired, operating conditions that promote the development of thin biofilms are required to ensure that oxygen penetration inside the biofilm is maximized. For the 2,000- $\mu \mathrm{m}$ thick biofilm, simulations were carried out for different numbers of layers (comprising the heterogeneous biofilm) in order to evaluate the impact of biofilm discretization on model outputs. The model with low discretization of the biofilm (i.e., 10 layers) predicted lower rates of carbon removal, nitrification, and denitrification than the model with high biofilm discretization (i.e., 60 layers). When simulating thick biofilms with a low discretization (e.g., 1,000 $\mu \mathrm{m}$ thick biofilm with 10 layers resulting in $100-\mu \mathrm{m}$ thick layers), the user should be aware of the fact that the biofilm model does not properly reflect substrate and biomass gradients expected in the real biofilm and, as a consequence, accurate system simulations will not result.

Simulation of combined carbon oxidation and nitrification in mixed culture biofilms is influenced by the assumed biofilm biomass distribution (Scenario II). A homogeneous biofilm biomass distribution reduces the competitive advantage possessed by faster growing heterotrophic bacteria in a heterogeneous (layered) 1-D biofilm model. This can be explained by the tendency of heterotrophs to dominate layers near the biofilm surface and have more direct access to substrates and macronutrients in the bulk of the liquid (Morgenroth 2003). Ammonium is of primary concern to many biofilm reactor process designers; therefore, ammonium flux is discussed $\left(\mathrm{J}_{\mathrm{NH} 4}\right)$. Ammonium flux is dependent on the ratio of bulk liquid soluble organic substrate-to-ammonium concentrations $\left(\mathrm{S}_{\mathrm{S}}: \mathrm{S}_{\mathrm{NH} 4}\right)$. In the case of a simulation describing one combined carbon oxidation and nitrification MBBR, $\mathrm{J}_{\mathrm{NH} 4}=0.63 \mathrm{~g} \mathrm{~m}^{-2} \mathrm{~d}^{-1}$ when $\mathrm{S}_{\mathrm{S}}: \mathrm{S}_{\mathrm{NH} 4}=2.25$ and $\mathrm{J}_{\mathrm{NH} 4}=0.60 \mathrm{~g} \mathrm{~m}^{-2} \mathrm{~d}^{-1}$ when 
$\mathrm{S}_{\mathrm{s}}: \mathrm{S}_{\mathrm{NH} 4}=1.42$ for assumed heterogeneous (layered) and homogeneous biofilm biomass distributions, respectively. This observation is consistent with the benchmark analysis, problems N1 and N1b, trends reported by Wanner et al. (2006). For models similar to those described in this paper, Wanner et al. (2006) reported $\mathrm{J}_{\mathrm{NH} 4}=0.88 \mathrm{~g} \mathrm{~m}^{-2} \mathrm{~d}^{-1}$ when $\mathrm{S}_{\mathrm{s}}: \mathrm{S}_{\mathrm{NH} 4}=3.39$ and $\mathrm{J}_{\mathrm{NH} 4}=0.74 \mathrm{~g} \mathrm{~m}^{-}$ ${ }^{2} \mathrm{~d}^{-1}$ when $\mathrm{S}_{\mathrm{S}}: \mathrm{S}_{\mathrm{NH} 4}=2.15$ for assumed heterogeneous (layered) and homogeneous biofilm biomass distributions, respectively. Alternatively, a tertiary nitrification MBBR simulation resulted in $\mathrm{J}_{\mathrm{NH} 4}=$ $1.28 \mathrm{~g} \mathrm{~m}^{-2} \mathrm{~d}^{-1}$ when $\mathrm{S}_{\mathrm{S}}: \mathrm{S}_{\mathrm{NH} 4}=0.39$ and $\mathrm{J}_{\mathrm{NH} 4}=1.29 \mathrm{~g} \mathrm{~m}^{-2} \mathrm{~d}^{-1}$ when $\mathrm{S}_{\mathrm{S}}: \mathrm{S}_{\mathrm{NH} 4}=0.38$ for assumed heterogeneous (layered) and homogeneous biofilm biomass distributions, respectively. Results from a modeling study (average $\mathrm{S}_{\mathrm{S}}: \mathrm{S}_{\mathrm{NH} 4}=0.23$ ) reported by Elenter et al. (2007) describe ammonium flux trends consistent with these tertiary nitrification MBBR modeling results.

Elenter et al. (2007) stated that the heterogeneous (layered) 1-D biofilm model over predicted the negative impact that heterotrophic bacteria over growth had on autotrophic nitrifying bacteria activity. Mixed-culture biofilms consisting of heterotrophic bacteria populating a majority of the biofilm surface and autotrophic nitrifiers existing closer to the growth medium has been demonstrated experimentally (Okabe et al. 1995). This observation is characterized by a continuum of layers in the heterogeneous 1-D biofilm model applied throughout this study. The same approach was applied to the referenced work by Wanner et al. (2006) and Elenter et al. (2007). However, systematic deviations between observed and simulated ammonium flux values prompted Elenter $e t$ al. (2007) to question their results. Autotrophic nitrifiers growing in mixed-culture biofilms actually develop in dense clusters that form microcolonies (Okabe at al. 1999; Kindaichi et al. 2004). These clusters of autotrophic nitrifiers may develop close to the biofilm surface and result in more substantial nitrification than is simulated with the aforementioned heterogeneous (layered) 1-D biofilm model. Elenter et al. (2007) used this explanation to justify the heterogeneous (layered) 1-D biofilm model under predicting ammonium flux and the homogeneous 1-D biofilm model ability to well-describe the observed ammonium flux.

Modeling conducted as a part of this study indicates that increasing $\mathrm{S}_{\mathrm{S}}: \mathrm{S}_{\mathrm{NH} 4}$ results in the heterogeneous (layered) 1-D biofilm model simulating a larger ammonium flux than the homogeneous 1-D biofilm model. It should be noted that biofilm thickness increased with increasing $\mathrm{S}_{\mathrm{S}}: \mathrm{S}_{\mathrm{NH} 4}$. The difference in ammonium flux (between heterogeneous and homogeneous biofilm models) is a result of the amount of autotrophic nitrifiers in the layered biofilm distinctly increasing with increasing biofilm thickness. Specifically, the largest increase was in the amount of nitrifiers in the upper (and aerobic) $50 \mu \mathrm{m}$ of the heterogeneous biofilm (where the nitrifiers are protected from detachment but are also made more available to dissolved oxygen in the bulk of the liquid). The assumption of a homogeneous biofilm does conceivably allow autotrophic nitrifiers to develop closer to the biofilm surface than does a heterogeneous biofilm model, but the nitrifier concentration is "diluted" over the entire biofilm thickness. For this reason one can predict, mathematically, the influence of organic matter on nitrification by assuming either a heterogeneous (layered) or homogeneous biofilm biomass distribution. Assuming a heterogeneous biofilm structure diminishes the importance of biofilm thickness since the portion of the biofilm near the growth medium-biofilm interface primarily consists of inert biomass. The homogeneous biofilm structure results in more "dilution" of biomass over the entire biofilm thickness where fewer autotrophic nitrifiers are exposed to dissolved oxygen in the bulk of the liquid. Therefore, ammonium flux is reduced for thicker biofilms that assume a homogeneous biofilm biomass distribution. 
External mass transfer resistance (Scenario III) had a considerable effect on the model outputs as aerobic carbon oxidation and nitrification increased for thinner or no external boundary layer due to increased mass transfer into the biofilm. Changing the mixing conditions of the reactor from completely mixed to plug-flow (modeled by several reactors in series; Scenario IV) clearly improved the removal efficiency of the reactor resulting in lower effluent concentrations for readily biodegradable substrate and ammonium. Temperature (Scenario V) does not only affect growth and endogenous respiration rates but also diffusivity of soluble substances. Carbon oxidation and nitrification efficiencies decreased with decreasing temperature due to lower bacterial activity and reduced diffusivity of soluble substances accounted for by temperature dependent diffusion coefficients (Table A4 in the Appendix). Low temperatures influenced nitrification considerably more than carbon oxidation. Biofilm thickness and biofilm structure had only a negligible impact on model results for tertiary nitrification and tertiary denitrification. Opposed to that, MTBL thickness and mixing conditions had a distinct impact on treatment performance. Both denitrification and nitrification increased for thinner MTBL thicknesses and when multiple CFSTRs are simulated. The authors acknowledge that many tertiary biofilm reactor configurations are fixed by system process mechanical components or capital and construction costs. Although less sensitive, the tertiary denitrification MBBR with methanol was sensitive to similar factors as the other systems evaluated (see Table 9). 


\section{WWTmod}

Table 7. Steady state simulation results for combined carbon oxidation and nitrification in an MBBR.

\begin{tabular}{|c|c|c|c|c|c|c|c|c|c|c|c|c|}
\hline \multirow[t]{2}{*}{ Scenario } & $\mathrm{S}_{\mathrm{NH} 4}$ & $\mathrm{~S}_{\mathrm{O} 2}$ & $\mathrm{~S}_{\mathrm{NO} 3}$ & $\mathrm{~S}_{\mathrm{S}}$ & $\mathrm{X}_{\mathrm{S}}$ & $\mathrm{S}_{\mathrm{N} 2}$ & $\mathrm{~J}_{\mathrm{NH} 4}$ & $\mathbf{J}_{\mathrm{NO} 3}$ & $\mathrm{~J}_{\mathrm{S}}$ & $\mathrm{J}_{\mathrm{O} 2}$ & $\mathrm{~J}_{\mathrm{XS}}$ & $\mathbf{J}_{\mathrm{N} 2}$ \\
\hline & \multicolumn{6}{|c|}{$\left[\mathrm{g} \mathrm{N} / \mathrm{m}^{3}, \mathrm{~g} \mathrm{COD} / \mathrm{m}^{3}\right]$} & \multicolumn{6}{|c|}{$\left[\mathrm{g} \mathrm{N} /\left(\mathrm{m}^{2} \cdot \mathrm{d}\right), \mathrm{g} \mathrm{COD} /\left(\mathrm{m}^{2} \cdot \mathrm{d}\right)\right]$} \\
\hline \multicolumn{13}{|c|}{ Scenario I: Impact of altering biofilm thickness and detachment model } \\
\hline$\underline{\mathrm{L}}_{\mathrm{E}}=200 \mu \mathrm{m}, 10$ layers ${ }^{(*)}$ & 1.4 & 4.0 & 20.3 & 3.2 & 223.2 & 1.5 & 0.63 & -0.53 & 1.88 & 3.51 & 0.13 & -0.04 \\
\hline $\mathrm{L}_{\mathrm{F}}=2,000 \mu \mathrm{m}, 10$ layers & 8.6 & 4.0 & 4.3 & 5.4 & 203.7 & 11.5 & 0.46 & -0.09 & 2.03 & 2.99 & 1.06 & -0.33 \\
\hline $\mathrm{L}_{\mathrm{F}}=2,000 \mu \mathrm{m}, 60$ layers ${ }^{(* * * * *)}$ & 2.7 & 4.0 & 12.8 & 3.6 & 202.8 & 8.2 & 0.62 & -0.32 & 2.08 & 3.62 & 1.02 & -0.23 \\
\hline $\mathrm{L}_{\mathrm{F}}=197 \mu \mathrm{m}, 10$ layers $^{(* *)}$ & 1.4 & 4.0 & 20.3 & 3.2 & 223.3 & 1.5 & 0.63 & -0.53 & 1.87 & 3.50 & 0.13 & -0.04 \\
\hline $\mathrm{L}_{\mathrm{F}}=1,241 \mu \mathrm{m}, 60$ layers ${ }^{(* * *)}$ & 2.4 & 4.0 & 16.6 & 3.4 & 210.0 & 4.4 & 0.61 & -0.42 & 1.98 & 3.59 & 0.69 & -0.12 \\
\hline \multicolumn{13}{|c|}{ Scenario II: Impact of assumed biofilm biomass distribution } \\
\hline$\underline{\text { Heterogeneous }}^{(*)}$ & 1.4 & 4.0 & 20.3 & 3.2 & 223.2 & 1.5 & 0.63 & -0.53 & 1.88 & 3.51 & 0.13 & -0.04 \\
\hline Homogeneous & 2.3 & 4.0 & 19.7 & 3.3 & 225.6 & 1.7 & 0.60 & -0.51 & 1.94 & 3.61 & 0.13 & -0.04 \\
\hline \multicolumn{13}{|c|}{ Scenario III: Impact of altering mass transfer boundary layer thickness } \\
\hline$\underline{\mathrm{L}}_{\mathrm{L}}=100 \mu \mathrm{m}^{(*)}$ & 1.4 & 4.0 & 20.3 & 3.2 & 223.2 & 1.5 & 0.63 & -0.53 & 1.88 & 3.51 & 0.13 & -0.04 \\
\hline $\mathrm{L}_{\mathrm{L}}=0 \mu \mathrm{m}$ & 0.8 & 4.0 & 21.6 & 1.6 & 223.3 & 0.7 & 0.67 & -0.58 & 2.32 & 3.86 & 0.13 & -0.02 \\
\hline $\mathrm{L}_{\mathrm{L}}=\mathrm{L}_{\mathrm{c}} / \mathrm{Sh}^{(* * * *)}$ & 1.1 & 4.0 & 21.1 & 2.3 & 223.3 & 1.0 & 0.65 & -0.56 & 2.09 & 3.70 & 0.13 & -0.03 \\
\hline \multicolumn{13}{|c|}{ Scenario IV: Impact of mixing regime on model results for $N$ continuous flow stirred tank reactors-in-series (CFSTR vs. plug-flow) } \\
\hline$\underline{\mathrm{N}}=1^{(*)}$ & 1.4 & 4.0 & 20.3 & 3.2 & 223.2 & 1.5 & 0.63 & -0.53 & 1.88 & 3.51 & 0.13 & -0.04 \\
\hline $\mathrm{N}=3$ & 0.5 & 4.0 & 20.3 & 0.6 & 224.2 & 2.3 & 0.67 & -0.53 & 2.20 & 3.61 & 0.11 & -0.06 \\
\hline $\mathrm{N}=6$ & 0.2 & 4.0 & 20.7 & 0.6 & 224.9 & 2.0 & 0.69 & -0.54 & 2.33 & 3.67 & 0.11 & -0.05 \\
\hline \multicolumn{13}{|c|}{ Scenario V: Impact of altering temperature } \\
\hline$\underline{\mathrm{T}}=20^{\circ} \mathrm{C}^{(*)}$ & 1.4 & 4.0 & 20.3 & 3.2 & 223.2 & 1.5 & 0.63 & -0.53 & 1.88 & 3.51 & 0.13 & -0.04 \\
\hline $\mathrm{T}=12^{\circ} \mathrm{C}$ & 6.6 & 4.0 & 14.9 & 4.6 & 230.6 & 1.6 & 0.50 & -0.39 & 2.01 & 2.81 & 0.10 & -0.04 \\
\hline
\end{tabular}

(*) Base scenario

(**) $\quad \mathrm{k}_{\text {detach }} \cdot \mathrm{L}_{\mathrm{F}}$ with $\mathrm{k}_{\text {detach }}=0.2\left[1 \mathrm{~d}^{-1}\right]$

(***) $\mathrm{k}_{\text {detach }} \cdot \mathrm{L}_{\mathrm{F}}^{2}$ with $\mathrm{k}_{\text {detach }}=30\left[1 \mathrm{~d}^{-1} \mathrm{~m}^{-1}\right]$

(****) Appendix A4. Calculated values: $\mathrm{L}_{\mathrm{L}, \mathrm{NH} 4}: 51 \mu \mathrm{m}, \mathrm{L}_{\mathrm{L}, \mathrm{NO} 3}: 50 \mu \mathrm{m}, \mathrm{L}_{\mathrm{L}, \mathrm{Ss}}: 43 \mu \mathrm{m}, \mathrm{L}_{\mathrm{L}, \mathrm{Xs}}: 36 \mu \mathrm{m}, \mathrm{L}_{\mathrm{L}, \mathrm{O} 2}: 55 \mu \mathrm{m}, \mathrm{L}_{\mathrm{L}, \mathrm{ALK}}: 43 \mu \mathrm{m}$

(*****) Simulations with 100 layers resulted in numerical insability. 
Table 8. Steady state simulation results for tertiary nitrification in an MBBR.

\begin{tabular}{|c|c|c|c|c|c|c|c|c|c|c|c|c|}
\hline \multirow[t]{2}{*}{ Scenario } & $\mathrm{S}_{\mathrm{NH} 4}$ & $\mathrm{~S}_{\mathrm{O} 2}$ & $\mathrm{~S}_{\mathrm{NO} 3}$ & $\mathrm{~S}_{\mathrm{S}}$ & $\mathrm{X}_{\mathrm{S}}$ & $\mathrm{S}_{\mathrm{N} 2}$ & $\mathbf{J}_{\mathrm{NH} 4}$ & $\mathbf{J}_{\mathrm{NO} 3}$ & $\mathrm{~J}_{\mathrm{S}}$ & $\mathrm{J}_{\mathrm{O} 2}$ & $\mathbf{J}_{\mathrm{XS}}$ & $\mathbf{J}_{\mathrm{N} 2}$ \\
\hline & \multicolumn{6}{|c|}{ 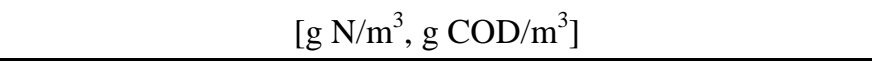 } & \multicolumn{6}{|c|}{$\left[\mathrm{g} \mathrm{N} /\left(\mathrm{m}^{2} \cdot \mathrm{d}\right), \mathrm{g} \mathrm{COD} /\left(\mathrm{m}^{2} \cdot \mathrm{d}\right)\right]$} \\
\hline \multicolumn{13}{|c|}{ Scenario I: Impact of altering biofilm thickness and detachment model } \\
\hline$\underline{L}_{\mathrm{F}}=200 \mu \mathrm{m}, 10$ layers ${ }^{(*)}$ & 1.9 & 5.0 & 21.4 & 0.7 & 7.8 & 0.3 & 1.29 & -1.25 & 0.32 & 5.79 & 0.00 & -0.02 \\
\hline $\begin{array}{l}\mathrm{L}_{\mathrm{F}}=2,000 \mu \mathrm{m}, 10 \text { layers, } \\
\text { actual } \mathrm{L}_{\mathrm{F}} 864 \mu \mathrm{m}\end{array}$ & 2.6 & 5.0 & 20.5 & 0.8 & 7.6 & 0.5 & 1.26 & -1.21 & 0.32 & 5.65 & 0.02 & -0.03 \\
\hline $\begin{array}{l}\mathrm{L}_{\mathrm{F}}=2,000 \mu \mathrm{m}, 100 \text { layers, } \\
\text { actual } \mathrm{L}_{\mathrm{F}} 877 \mu \mathrm{m}\end{array}$ & 1.9 & 5.0 & 21.4 & 0.7 & 7.6 & 0.3 & 1.29 & -1.25 & 0.32 & 5.80 & 0.02 & -0.02 \\
\hline $\mathrm{L}_{\mathrm{F}}=67 \mu \mathrm{m}, 10$ layers $^{(* *)}$ & 2.1 & 5.0 & 21.3 & 0.7 & 7.8 & 0.1 & 1.27 & -1.24 & 0.32 & 5.67 & 0.00 & -0.01 \\
\hline $\mathrm{L}_{\mathrm{F}}=622 \mu \mathrm{m}, 30$ layers $^{\left({ }^{* * *}\right)}$ & 1.9 & 5.0 & 21.4 & 0.7 & 7.7 & 0.3 & 1.29 & -1.25 & 0.32 & 5.80 & 0.01 & -0.02 \\
\hline \multicolumn{13}{|c|}{ Scenario II: Impact of assumed biofilm biomass distribution } \\
\hline$\underline{\text { Heterogeneous }}^{(*)}$ & 1.9 & 5.0 & 21.4 & 0.7 & 7.8 & 0.3 & 1.29 & -1.25 & 0.32 & 5.79 & 0.00 & -0.02 \\
\hline Homogeneous & 1.9 & 5.0 & 21.0 & 0.7 & 7.8 & 0.7 & 1.29 & -1.23 & 0.32 & 5.80 & 0.00 & -0.05 \\
\hline \multicolumn{13}{|c|}{ Scenario III: Impact of altering mass transfer boundary layer thickness } \\
\hline$\underline{\mathrm{L}}_{\mathrm{L}}=100 \mu \mathrm{m}{ }^{(*)}$ & 1.9 & 5.0 & 21.4 & 0.7 & 7.8 & 0.3 & 1.29 & -1.25 & 0.32 & 5.79 & 0.00 & -0.02 \\
\hline $\mathrm{L}_{\mathrm{L}}=0 \mu \mathrm{m}$ & 0.8 & 5.0 & 22.7 & 0.4 & 7.8 & 0.1 & 1.36 & -1.34 & 0.35 & 6.19 & 0.00 & -0.01 \\
\hline $\mathrm{L}_{\mathrm{L}}=\mathrm{L}_{\mathrm{c}} / \mathrm{Sh}^{(* * * *)}$ & 1.3 & 5.0 & 22.2 & 0.6 & 7.8 & 0.2 & 1.33 & -1.30 & 0.34 & 6.03 & 0.00 & -0.01 \\
\hline \multicolumn{13}{|c|}{ Scenario IV: Impact of mixing regime on model results for $N$ continuous flow stirred tank reactors-in-series (CFSTR vs. plug-flow) } \\
\hline$\underline{\mathrm{N}=1^{(*)}}$ & 1.9 & 5.0 & 21.4 & 0.7 & 7.8 & 0.3 & 1.29 & -1.25 & 0.32 & 5.79 & 0.00 & -0.02 \\
\hline $\mathrm{N}=3$ & 1.0 & 5.0 & 22.2 & 0.3 & 7.7 & 0.5 & 1.35 & -1.30 & 0.35 & 6.01 & 0.00 & -0.03 \\
\hline $\mathrm{N}=6$ & 0.5 & 5.0 & 22.5 & 0.2 & 7.7 & 0.5 & 1.38 & -1.33 & 0.36 & 6.12 & 0.00 & -0.03 \\
\hline \multicolumn{13}{|c|}{ Scenario V: Impact of altering temperature } \\
\hline$\underline{\mathrm{T}}=20^{\circ} \mathrm{C}^{(*)}$ & 1.9 & 5.0 & 21.4 & 0.7 & 7.8 & 0.3 & 1.29 & -1.25 & 0.32 & 5.79 & 0.00 & -0.02 \\
\hline $\mathrm{T}=12^{\circ} \mathrm{C}$ & 6.1 & 5.0 & 17.2 & 0.9 & 7.9 & 0.3 & 1.03 & -0.99 & 0.31 & 4.59 & 0.00 & -0.02 \\
\hline
\end{tabular}

\footnotetext{
(*) Base scenario

(**) $\quad \mathrm{k}_{\mathrm{detach}} \cdot \mathrm{L}_{\mathrm{F}}$

(***) $\quad \mathrm{k}_{\mathrm{detach}} \cdot \mathrm{L}_{\mathrm{F}}^{2}$

(****) Appendix A4. Calculated values: $\mathrm{L}_{\mathrm{L}, \mathrm{NH} 4}: 51 \mu \mathrm{m}, \mathrm{L}_{\mathrm{L}, \mathrm{NO} 3}: 50 \mu \mathrm{m}, \mathrm{L}_{\mathrm{L}, \mathrm{Ss}}: 43 \mu \mathrm{m}, \mathrm{L}_{\mathrm{L}, \mathrm{Xs}}: 36 \mu \mathrm{m}, \mathrm{L}_{\mathrm{L}, \mathrm{O} 2}: 55 \mu \mathrm{m}, \mathrm{L}_{\mathrm{L}, \mathrm{ALK}}: 43 \mu \mathrm{m}$
} 


\section{WWTmod}

Table 9. Steady state simulation results for tertiary denitrification with methanol in an MBBR.

\begin{tabular}{|c|c|c|c|c|c|c|c|c|c|c|c|c|}
\hline \multirow[t]{2}{*}{ Scenario } & $\mathrm{S}_{\mathrm{NH} 4}$ & $\mathrm{~S}_{\mathrm{NO} 3}$ & $\mathrm{~S}_{\mathrm{S}}$ & $\mathrm{S}_{\mathrm{M}}$ & $\mathrm{X}_{\mathrm{S}}$ & $\mathrm{S}_{\mathrm{N} 2}$ & $\mathbf{J}_{\mathrm{NH} 4}$ & $\mathbf{J}_{\mathrm{NO} 3}$ & $\mathbf{J}_{\mathrm{S}}$ & $\mathrm{J}_{\mathrm{M}}$ & $\mathbf{J}_{\mathrm{XS}}$ & $\mathbf{J}_{\mathrm{N} 2}$ \\
\hline & \multicolumn{6}{|c|}{$\left[\mathrm{g} \mathrm{N} / \mathrm{m}^{3}, \mathrm{~g} \mathrm{COD} / \mathrm{m}^{3}\right]$} & \multicolumn{6}{|c|}{$\left[\mathrm{g} \mathrm{N} /\left(\mathrm{m}^{2} \cdot \mathrm{d}\right), \mathrm{g} \mathrm{COD} /\left(\mathrm{m}^{2} \cdot \mathrm{d}\right)\right]$} \\
\hline \multicolumn{13}{|c|}{ Scenario I: Impact of altering biofilm thickness and detachment model } \\
\hline$\underline{\mathrm{L}}_{\mathrm{E}}=200 \mu \mathrm{m}, 10$ layers $^{(*)}$ & 1.6 & 2.0 & 0.3 & 1.4 & 0.2 & 3.1 & 0.04 & 0.30 & 0.08 & 1.33 & 0.00 & -0.30 \\
\hline $\mathrm{L}_{\mathrm{F}}=2,000 \mu \mathrm{m}, 10$ layers & 1.7 & 1.9 & 0.3 & 1.6 & 0.2 & 3.2 & 0.04 & 0.35 & 0.08 & 1.45 & 0.00 & -0.35 \\
\hline $\mathrm{L}_{\mathrm{F}}=2,000 \mu \mathrm{m}, 100$ layers & 1.6 & 1.8 & 0.2 & 0.6 & 0.2 & 3.3 & 0.04 & 0.33 & 0.09 & 1.43 & 0.00 & -0.33 \\
\hline $\mathrm{L}_{\mathrm{F}}=110 \mu \mathrm{m}, 10$ layers & 1.6 & 2.0 & 0.3 & 1.4 & 0.2 & 3.1 & 0.04 & 0.30 & 0.08 & 1.32 & 0.00 & -0.30 \\
\hline $\mathrm{L}_{\mathrm{F}}=848 \mu \mathrm{m}, 40$ layers & 1.6 & 2.0 & 0.3 & 1.4 & 0.2 & 3.1 & 0.04 & 0.30 & 0.08 & 1.33 & 0.00 & -0.30 \\
\hline \multicolumn{13}{|c|}{ Scenario II: Impact of assumed biofilm biomass distribution } \\
\hline$\underline{\text { Heterogeneous }}^{(*)}$ & 1.6 & 2.0 & 0.3 & 1.4 & 0.2 & 3.1 & 0.04 & 0.30 & 0.08 & 1.33 & 0.00 & -0.30 \\
\hline Homogeneous & 1.6 & 1.9 & 0.3 & 1.4 & 0.2 & 3.2 & 0.03 & 0.31 & 0.07 & 1.33 & 0.00 & -0.31 \\
\hline \multicolumn{13}{|c|}{ Scenario III: Impact of altering mass transfer boundary layer thickness } \\
\hline$\underline{\mathrm{L}}_{\mathrm{L}}=100 \mu \mathrm{m}^{(*)}$ & 1.6 & 2.0 & 0.3 & 1.4 & 0.2 & 3.1 & 0.04 & 0.30 & 0.08 & 1.33 & 0.00 & -0.30 \\
\hline $\mathrm{L}_{\mathrm{L}}=0 \mu \mathrm{m}$ & 1.6 & 1.8 & 0.2 & 0.5 & 0.2 & 3.3 & 0.04 & 0.32 & 0.08 & 1.42 & 0.00 & -0.32 \\
\hline $\mathrm{L}_{\mathrm{L}}=\mathrm{L}_{\mathrm{c}} / \mathrm{Sh}^{(* *)}$ & 1.6 & 1.9 & 0.3 & 1.0 & 0.2 & 3.2 & 0.04 & 0.31 & 0.08 & 1.37 & 0.00 & -0.31 \\
\hline \multicolumn{13}{|c|}{ Scenario IV: Impact of mixing regime on model results for $N$ continuous flow stirred tank reactors-in-series (CFSTR vs. plug-flow) } \\
\hline${\underline{\mathrm{N}}=1^{(*)}}^{\left(* x^{2}\right.}$ & 1.6 & 2.0 & 0.3 & 1.4 & 0.2 & 3.1 & 0.04 & 0.30 & 0.08 & 1.33 & 0.00 & -0.30 \\
\hline $\mathrm{N}=3$ & 1.6 & 1.8 & 0.2 & 0.2 & 0.2 & 3.3 & 0.04 & 0.33 & 0.09 & 1.45 & 0.00 & -0.33 \\
\hline$N=6$ & 1.6 & 1.8 & 0.1 & 0.0 & 0.2 & 3.4 & 0.04 & 0.33 & 0.09 & 1.47 & 0.00 & -0.33 \\
\hline \multicolumn{13}{|c|}{ Scenario V: Impact of altering temperature } \\
\hline$\underline{\mathrm{T}}=20^{\circ} \mathrm{C}^{(*)}$ & 1.6 & 2.0 & 0.3 & 1.4 & 0.2 & 3.1 & 0.04 & 0.30 & 0.08 & 1.33 & 0.00 & -0.30 \\
\hline $\mathrm{T}=12^{\circ} \mathrm{C}$ & 1.7 & 2.1 & 0.4 & 2.1 & 0.2 & 3.0 & 0.03 & 0.29 & 0.07 & 1.27 & 0.00 & -0.29 \\
\hline
\end{tabular}

*) Base scenario

(**) $\quad \mathrm{k}_{\text {detach }} \cdot \mathrm{L}_{\mathrm{F}}$

(***) $\mathrm{k}_{\text {detach }} \cdot \mathrm{L}_{\mathrm{F}}^{2}$

${ }^{(* * * *)}$ Appendix A4. Calculated values: $\mathrm{L}_{\mathrm{L}, \mathrm{NH} 4}: 51 \mu \mathrm{m}, \mathrm{L}_{\mathrm{L}, \mathrm{NO} 3}: 50 \mu \mathrm{m}, \mathrm{L}_{\mathrm{L}, \mathrm{SS}}: 43 \mu \mathrm{m}, \mathrm{L}_{\mathrm{L}, \mathrm{Xs}}: 36 \mu \mathrm{m}, \mathrm{L}_{\mathrm{L}, \mathrm{O} 2}: 55 \mu \mathrm{m}, \mathrm{L}_{\mathrm{L}, \mathrm{ALK}}: 43 \mu \mathrm{m}$ 
Table 10. Steady state simulation results for carbon oxidation and nitrification in the IFAS.

\begin{tabular}{|c|c|c|c|c|c|c|c|c|c|c|c|c|}
\hline \multirow[t]{2}{*}{ Scenario } & $\mathrm{S}_{\mathrm{NH} 4}$ & $\mathrm{~S}_{\mathrm{O} 2}$ & $\mathrm{~S}_{\mathrm{NO} 3}$ & $\mathrm{~S}_{\mathrm{S}}$ & $\mathrm{X}_{\mathrm{S}}$ & $\mathrm{S}_{\mathrm{N} 2}$ & $\mathrm{~J}_{\mathrm{NH} 4}$ & $\mathrm{~J}_{\mathrm{NO} 3}$ & $\mathrm{~J}_{\mathrm{SS}}$ & $\mathrm{J}_{\mathrm{O} 2}$ & $\mathrm{~J}_{\mathrm{XS}}$ & $\mathrm{J}_{\mathrm{N} 2}$ \\
\hline & \multicolumn{7}{|c|}{$\left[\mathrm{g} \mathrm{N} / \mathrm{m}^{3}, \mathrm{~g} \mathrm{COD} / \mathrm{m}^{3}\right]$} & \multicolumn{5}{|c|}{$\left[\mathrm{g} \mathrm{N} /\left(\mathrm{m}^{2} \cdot \mathrm{d}\right), \mathrm{g} \mathrm{COD} /\left(\mathrm{m}^{2} \cdot \mathrm{d}\right)\right]$} \\
\hline \multicolumn{13}{|c|}{ Scenario III: Impact of altering mass transfer boundary layer thickness } \\
\hline$\underline{\mathrm{L}}_{\mathrm{L}}=100 \mu \mathrm{m}^{(*)}$ & 2.4 & 4.0 & 22.7 & 0.4 & 220.2 & 0.4 & 1.02 & -1.00 & 0.06 & 4.44 & 0.02 & 0.00 \\
\hline $\mathrm{L}_{\mathrm{L}}=0 \mu \mathrm{m}$ & 1.5 & 4.0 & 23.6 & 0.4 & 220.3 & 0.4 & 1.21 & -1.18 & 0.42 & 5.44 & 0.04 & 0.00 \\
\hline $\mathrm{L}_{\mathrm{L}}=\mathrm{L}_{\mathrm{c}} / \mathrm{Sh}^{(* *)}$ & 1.8 & 4.0 & 23.2 & 0.4 & 220.2 & 0.4 & 1.14 & -1.12 & 0.13 & 5.00 & 0.03 & 0.00 \\
\hline \multicolumn{13}{|c|}{ Scenario V: Impact of altering temperature } \\
\hline$\underline{\mathrm{T}=20^{\circ} \mathrm{C}^{(*)}}$ & 2.4 & 4.0 & 22.7 & 0.4 & 220.2 & 0.4 & 1.02 & -1.00 & 0.06 & 4.44 & 0.02 & 0.00 \\
\hline $\mathrm{T}=12^{\circ} \mathrm{C}$ & 19.1 & 4.0 & 6.1 & 0.7 & 229.3 & 0.3 & 0.21 & -0.20 & 0.12 & 0.95 & 0.01 & 0.00 \\
\hline
\end{tabular}

In addition to submerged biofilm reactors for different wastewater treatment scenarios, we also studied an IFAS system for combined carbon oxidation and nitrification (Table 10). The mixed liquor suspended solids (MLSS) concentration was approximately $2,800 \mathrm{~g} \mathrm{~m}^{-3}$. In the IFAS process, organic carbon was primarily oxidized by suspended heterotrophic bacteria in the bulk phase. Only $2 \%$ of the carbon oxidation took place in the biofilm resulting in a higher ammonium flux in the biofilm compartment compared with the submerged biofilm system. Nitrification in the MBBR for combined carbon oxidation and nitrification is lower as nitrifiers have to compete with heterotrophic bacteria for space and oxygen in the biofilm. Nitrification in the biofilm significantly increases when organic substrate loading decreases or is removed by heterotrophs in the MLSS.

\section{Sensitivity analysis}

Sensitivity measures $\delta$ for biokinetic and biofilm parameters are presented in Figure 3 and Figure 4 for IFAS and three municipal WWT scenarios for MBBRs. Results presented in Figure 3 are for 20 ${ }^{\circ} \mathrm{C}$, in Figure 4 for $12{ }^{\circ} \mathrm{C}$. For IFAS, combined carbon oxidation and nitrification, and tertiary nitrification, the sensitivity measure $\delta$ was calculated for each parameter based on sensitivity values for ammonium, nitrate, and soluble bulk liquid organic substrate $\left(\mathrm{S}_{\mathrm{S}}\right)$ concentration, and sensitivity values for fluxes of ammonium, nitrate, soluble organic substrate. For tertiary denitrification, $\delta$ was calculated based on sensitivity values for nitrate, organic substrate $\left(S_{S}\right)$, and methanol in the bulk liquid, and sensitivity values for fluxes of nitrate, organic substrate $\left(S_{S}\right)$, methanol, and dinitrogen. The parameters that have the most substantial impact on model outputs depend on the treatment system under study and the selected model outputs. For combined carbon oxidation and nitrification, $\mu_{\mathrm{H}}$ and $\mathrm{K}_{\mathrm{S}, \mathrm{H}}$ had a large influence on bulk phase concentrations and fluxes through the biofilm surface pointing to a large influence of carbon oxidation on nitrification due to competition of heterotrophic and autotrophic organisms (Figure 3). In addition, MTBL thickness and the $\mathrm{O}_{2}$ diffusion coefficient affected model results and shows that $\mathrm{O}_{2}$ supply is critical. For tertiary nitrification, the MTBL thickness had the largest impact on bulk phase concentrations followed by the diffusion coefficient for oxygen. Oxygen supply to the biofilm is more important for tertiary nitrification than biokinetic parameters. Tertiary denitrification is mainly driven by the MTBL thickness and the diffusion coefficient for methanol, the main substrate for denitrification. IFAS is mainly impacted by the biokinetic parameters $\mu_{\mathrm{A}}, \mu_{\mathrm{H}}, \mathrm{k}_{\mathrm{H}}$, and $\mathrm{K}_{\mathrm{S}, \mathrm{H}}$ and MTBL thickness. Diffusion coefficients had a minor impact on the model results. At $12^{\circ} \mathrm{C}$ model results for the IFAS are extremely sensitive to parameter changes in $\mu_{\mathrm{A}}$ and $\mathrm{K}_{\mathrm{O} 2, \mathrm{~A}}$ (Figure 4). 
IFAS: Carbon oxidation and nitrification

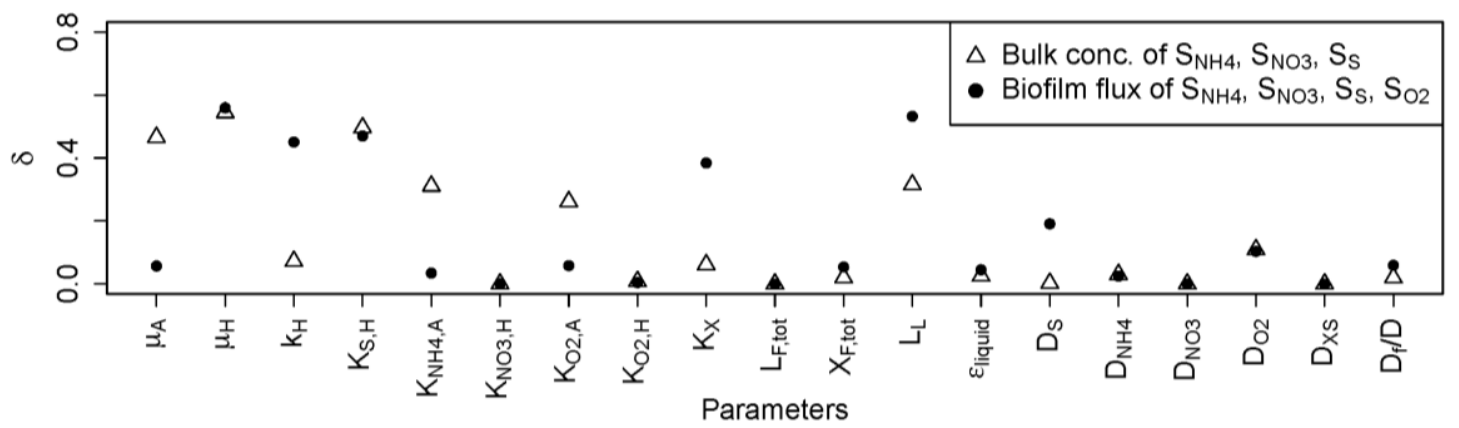

Carbon oxidation and nitrification

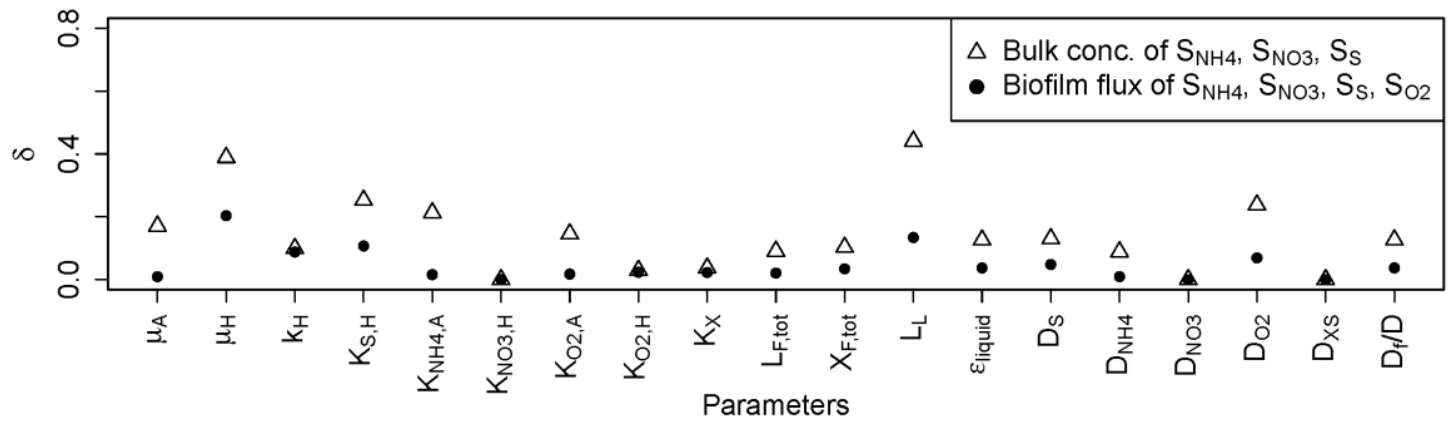

Tertiary nitrification

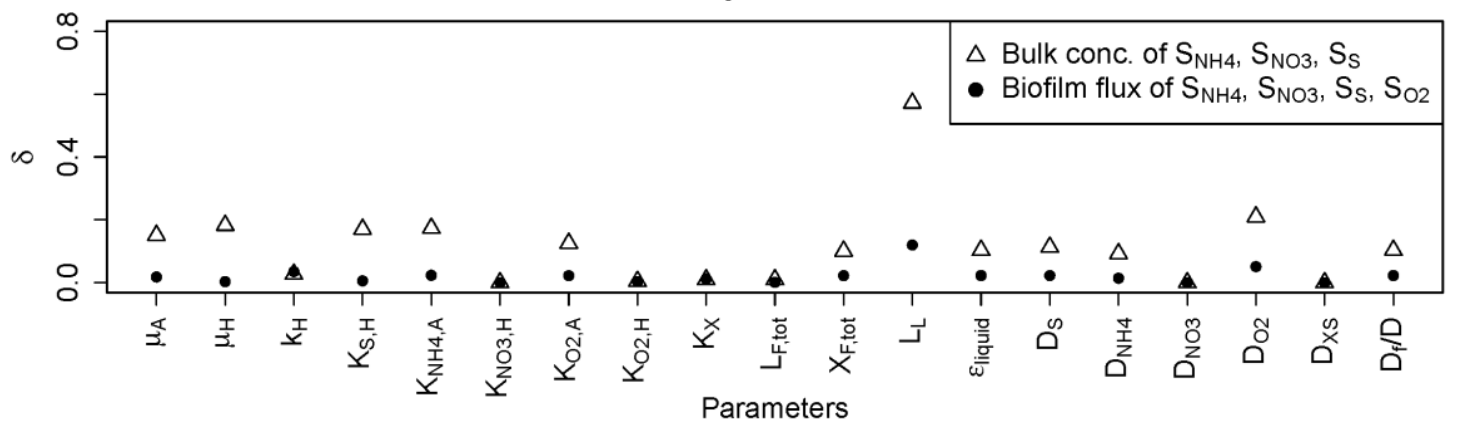

Post-denitrification

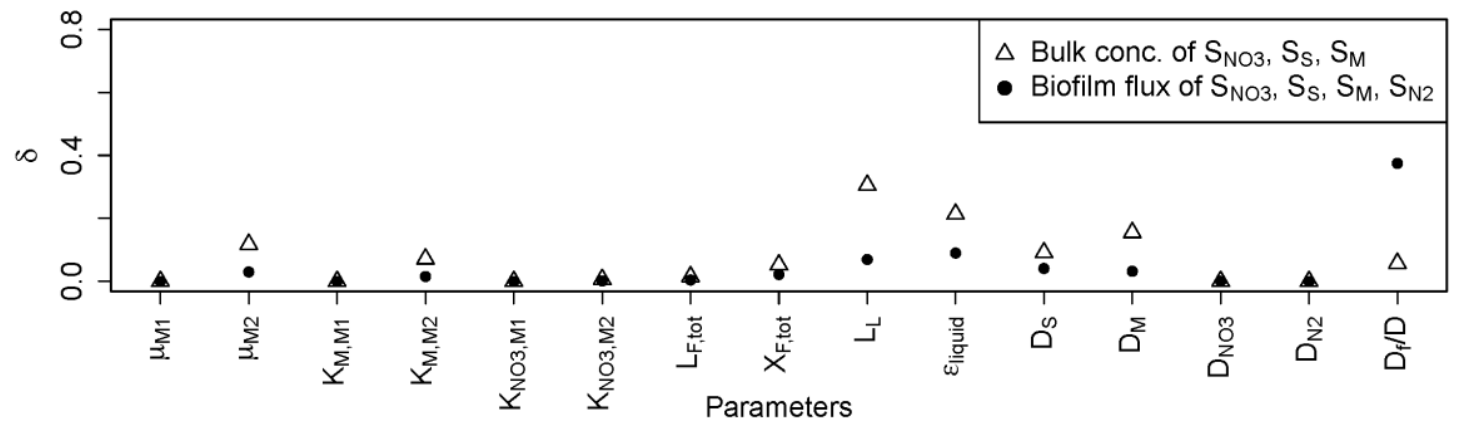

Figure 3. Sensitivity measures $\delta$ for biokinetic and biofilm parameters for simulations at $20^{\circ} \mathrm{C}$ (Scenario VI). For IFAS, combined carbon oxidation and nitrification, and tertiary nitrifications, $\delta$ is given for bulk concentrations of ammonium, nitrate and organic carbon (together), and fluxes of ammonium, nitrate, organic carbon, and oxygen through the biofilm surface (together). For tertiary denitrification, $\delta$ is given for bulk concentrations of nitrate, organic carbon $\left(\mathrm{S}_{\mathrm{S}}\right)$, and methanol (together), and fluxes of nitrate, organic carbon $\left(\mathrm{S}_{\mathrm{S}}\right)$, methanol, and dinitrogen through the biofilm surface. 
IFAS: Carbon oxidation and nitrification

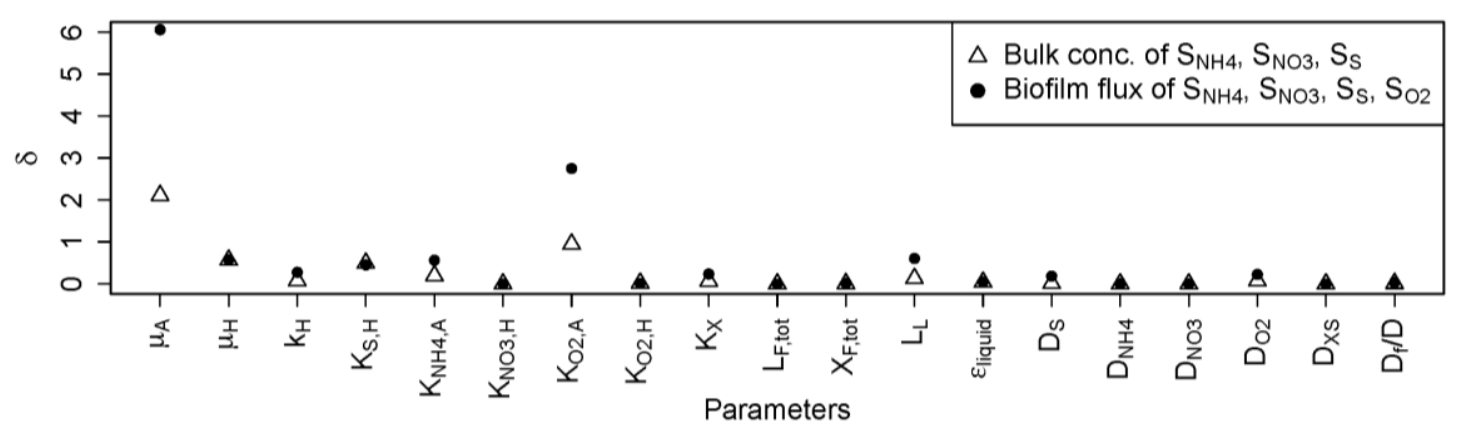

Carbon oxidation and nitrification

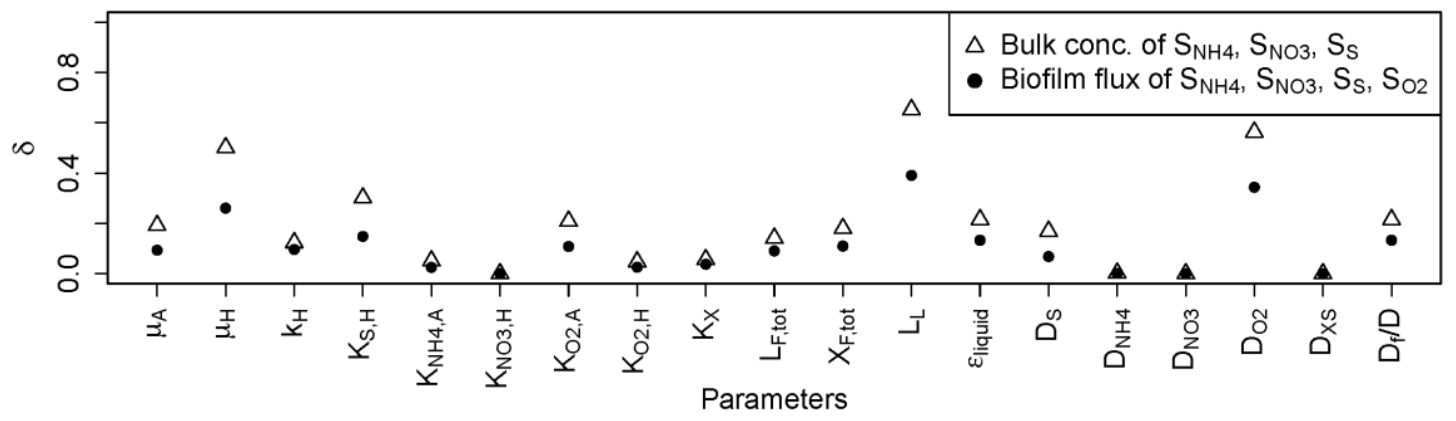

Tertiary nitrification

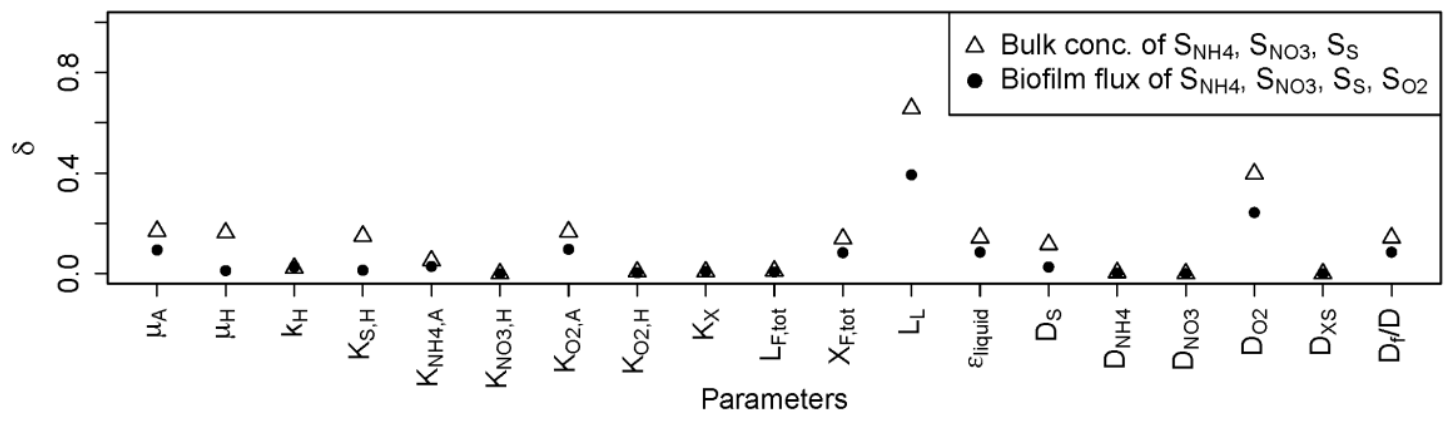

Post-denitrification

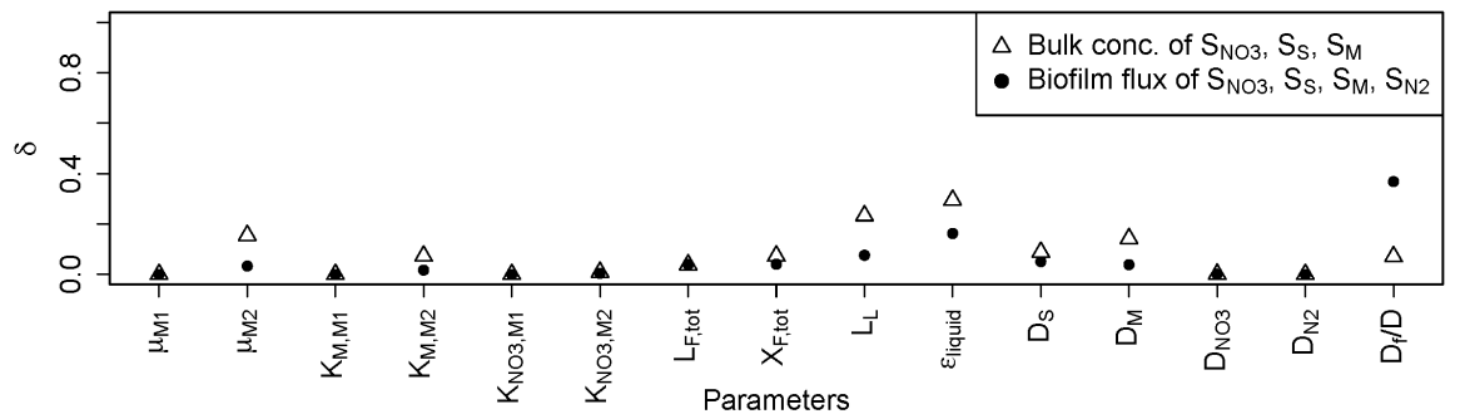

Figure 4: Sensitivity measures $\delta$ for biokinetic and biofilm parameters for simulations at $12^{\circ} \mathrm{C}$ (Scenario VI). For IFAS, combined carbon oxidation and nitrification, and tertiary nitrifications, $\delta$ is given for bulk concentrations of ammonium, nitrate and organic carbon (together), and fluxes of ammonium, nitrate, organic carbon, and oxygen through the biofilm surface (together). For tertiary denitrification, $\delta$ is given for bulk concentrations of nitrate, organic carbon $\left(S_{S}\right)$, and methanol (together), and fluxes of nitrate, organic carbon $\left(\mathrm{S}_{\mathrm{S}}\right)$, methanol, and dinitrogen through the biofilm surface. Note that for IFAS, the scale of the y-axis is different. 
Independent of the biofilm system under investigation, the MTBL thickness had an important influence on model outputs of the three biofilm systems. In addition, the diffusion coefficient for oxygen had a large impact on model results for aerobic biofilm systems, and the diffusion coefficient for methanol on model outputs for the denitrification biofilm system. The thickness of the external mass transfer boundary layer and the mentioned diffusion coefficients are, therefore, important parameters in biofilm models followed by biokinetic parameters of the dominating organism specie in the biofilm.

\section{CONCLUSIONS}

The following conclusions have been derived from the work presented in this paper.

- Ad-hoc expert-based trial and error calibration allows the user to fit certain model predictions (e.g., biofilm thickness and mixed liquor suspended solids). Such a calibration technique, however, may have limited applicability as resulting parameters are often not sufficiently general to predict system performance during other periods even for the same wastewater treatment plant.

- The use of lumped parameters (e.g., $\mathrm{K}_{\mathrm{O} 2, \mathrm{~A}}, \mathrm{~b}_{\mathrm{res}}, \mathrm{k}_{\mathrm{at}}, \mathrm{k}_{\mathrm{det}}, \mathrm{L}_{\mathrm{L}}$, and $\mathrm{D}_{\mathrm{F}} / \mathrm{D}$ ) makes the calibration of models with a biofilm compartment difficult and unreliable. Additional research is required to identify trends in lumped parameter variability and develop mathematical expressions describing the variability. Alternatively, existing mathematical models require revision and/or expansion to include an improved mechanistic description of the processes relying on these lumped parameters that is based on a set of fixed, reliable parameters.

- At both temperatures studied, each system modeled was very sensitive to changes in the biofilm parameter mass transfer boundary layer thickness $\left(\mathrm{L}_{\mathrm{L}}\right)$.

- Model predictions are sensitive to kinetic and biofilm parameters for the case of combined carbon oxidation and nitrification IFAS and MBBR, and tertiary nitrification MBBR. Furthermore, the sensitivity of model predictions to kinetic and biofilm parameters are strongly influenced by temperature. For the case of combined carbon oxidation and nitrification IFAS, system performance was dominated by the maximum growth rate of autotrophic bacteria $\left(\mu_{\mathrm{A}}\right)$ at $\mathrm{T}=12^{\circ} \mathrm{C}$, but this was not the case at $\mathrm{T}=20^{\circ} \mathrm{C}$. The same trend was observed for the oxygen affinity constant of autotrophic bacteria $\left(\mathrm{K}_{\mathrm{O} 2, \mathrm{~A}}\right)$.

- Cold temperature local sensitivity analysis provides evidence that biofilm models are sensitive to changes in mass transfer boundary layer thickness $\left(\mathrm{L}_{\mathrm{L}}\right)$, diffusivity coefficient (D), maximum growth rate $(\mu)$, and affinity constant $(\mathrm{K})$ for the rate-limiting substrate. In essence, model results are controlled by user-defined parameter values for the mass transfer and biochemical transformation for the substrate that is least available inside the biofilm.

- No simple recommendations for a generally applicable model calibration methodology can be suggested as the sensitivity of model predictions significantly depends on environmental conditions (e.g., temperature) and treatment objectives (e.g., nitrification, denitrification). A preliminary modeling study and sensitivity analysis to identify system-specific sensitive parameters may serve to guide testing program design. 


\section{REFERENCES}

ATV (2002). Neue Erkenntnisse über Anlagen mit getauchtem Festbett, Arbeitsbericht der ATV-DVWK Arbeitsgruppe KA-6.3 "Tropf- und Tauchkörper". Korrespondenz Abwasser 49(12), 1703-1707 (in German).

Beyenal, H., and Lewandowski, Z. (2000). Combined effect of substrate concentration and flow velocity on effective diffusivity in biofilms. Wat. Res. 34(2). 528-538.

Bilyk, K., Takács, I., Rohrbacher, J., Pitt, P., Latimer, R., and Dold, P. (2008). Full-scale testing advances fundamental understanding of denitrification filtres. Proceedings of the 81st Annual Water Environment Federation Technical Exhibition and Conference (WEFTEC). Chicago, Illinois, USA.

Bishop, P.L. (2003). The effect of biofilm heterogeneity on metabolic processes. In: Wuertz, S., Wilderer, P.A., and Bishop, P.L. (Eds.), Biofilms in Wastewater Treatment. IWA Publishing, London, UK.

Boltz, J.P., Morgenroth, E., and Sen, D. (2010a). Mathematical modelling of biofilms and biofilm reactors for engineering design. Wat. Sci. Tech. In press.

Boltz, J.P., Morgenroth, E., deBarbadillo, C., Dempsey, M., McQuarrie, J., Ghylin, T., Harrison, J., and Nerenberg, R. (2010b). Biofilm Reactor Technology and Design (Chapter 13). In: Design of Municipal Wastewater Treatment Plants, Volume 2, Fifth Edition. WEF Manual of Practice No. 8, ASCE Manuals and Reports on Engineering Practice No. 76. McGraw Hill. New York, USA. ISBN P/N 978-0-07-166360-1 of set 978-0-07-166358-8 (MHID $\mathrm{P} / \mathrm{N}$ 0-07-166360-6 of set 0-07-166358-4).

Boltz, J.P., Johnson, B.R., Daigger, G.T., and Sandino, J. (2009). Modeling integrated fixed film activated sludge (IFAS) and moving bed biofilm reactor (MBBR) systems I: mathematical treatment and model development. Wat. Env. Res. 81(6), 555-575.

Boltz, J.P, and La Motta, E.J. (2007). The kinetics of particulate organic matter removal as a response to bioflocculation in aerobic biofilm reactors. Wat. Env. Res. 79. 725-735.

Brito, A., and Melo, L. (1999). Mass transfer coefficients within anaerobic biofilms: effects of external liquid velocity. Wat. Res. 33(17). 3673-3678.

Brockmann, D., Rosenwinkel, K.-H., and Morgenroth E. (2008). Practical identifiability of biokinetic parameters of a model describing two-step nitrification in biofilms. Biotech. Bioeng. 101(3). 497-514.

Brun, R., Kühni, M., Siegrist, H., Gujer, W. and Reichert, P. (2002) Practical identifiability of ASM2d parameters systematic selection and tuning of parameter subsets. Wat. Res. 36(16), 4113-4127.

Brun, R., Reichert, P. and Kunsch, H.R. (2001) Practical identifiability analysis of large environmental simulation models. Water Res. Res. 37(4), 1015-1030.

Elenter, D., Milferstedt, K., Zhang, W., Hausner, M., and Morgenroth, E. (2007). Influence of detachment on substrate removal and microbial ecology in a heterotrophic/autotrophic biofilm. Wat. Res. 41(20). 4657-4671.

Hauduc, H., Rieger, L., Ohtsuki, T., Shaw, A., Takács, I., Winkler, S., Héduit, A., Vanrolleghem, P.A., and Gillot, S. (2010). Activated sludge modelling: development and potential use of a practical applications database. Proceedings of IWA/WEF WWTmod 2010. Quebec (QC), Canada. March.

Henze, M., Gujer, W., Mino, T., Matsuo, T., Wentzel, M., Marais, G.v.R., and van Loosdrecht, M.C.M. (2000). Activated Sludge Model No. 2d. In: Activated Sludge Models ASM1, ASM2, ASM2d, and ASM3. Scientific and Technical Report No. 9. Henze, M., Gujer, W., Mino, T., van Loosdrecht, M.C.M., Eds. IWA Publishing. London, U.K.

Hydromantis, Inc. (2006). Attached Growth Models. In (unpublished): GPS-X Technical Reference. 157-185.

Kim, H.-S., Pei, R., Boltz, J.P., Gellner, J.W., Gunsch, C., Freudenberg, R.G., Dodson, R., and Schuler, A.J. (2010). Attached and suspended phase nitrifying microbial community structures and functions in integrated fixed film activated sludge. Water Env. Res. Invited article accepted with minor revision.

Kindaichi, T., Ito, T., Okabe, S. (2004). Ecophysiological interaction between nitrifying bacteria and heterotrophic bacteria in autotrophic nitrifying biofilms as determined by microautoradiography-fluorescence in situ hybridization. Appl. Environ. Microbiol. 70(3). 1641-1650.

Kissel, J.C., McCarty, P.L., and Street, R.L. (1984). Numerical simulations of mixed-culture biofilms. J. Env. Eng. 110. 393-411.

McGehee, M., Gellner, J., Beck, J., White, C., Bruton, T., and Howard, D. (2009). BioWin modeling of a three reactor IFAS system. Proceedings of the $82^{\text {nd }}$ Annual Water Environment Federation Technical Exhibition and Conference (WEFTEC), WEF, Orlando, FL.

Morgenroth, E. (2003). Detachment-an often overlooked phenomenon in biofilm research and modelling. In: Wuertz, S., Wilderer, P.A., and Bishop, P.L. (Eds.), Biofilms in Wastewater Treatment. IWA Publishing, London, UK.

Morgenroth, E. (2008) Modeling biofilms. In: Biological wastewater treatment - principles, modelling, and design. Henze, M., van Loosdrecht, M.C.M., Ekama, G. and Brdjanovic, D. (eds), IWA Publishing, London, UK.

Morgenroth, E.T., and Wilderer, P.A. (2000). Influence of detachment mechanisms on competition in biofilms. Wat. Res. 34(2). 417-426.

Morgenroth, E., Eberl, H.J. and van Loosdrecht, M.C.M. (2000) Evaluating 3-D and 1-D mathematical models for mass transport in heterogeneous biofilms. Wat. Sci. Tech. 41(4-5), 347-356. 
Okabe, S., Satoh, H., Watanabe, Y. (1999). In situ analysis of nitrifying biofilms as determined by in situ hybridization and the use of microelectrodes. Appl. Environ. Microbiol. 65(7). 3182-3191.

Picioreanu, C. (1999). Multidimensional modeling of biofilm structure. Ph.D. thesis. Department of Biotechnology, Delft University of Technology, Delft, The Netherlands.

Rauch, W., Vanhooren, H., and Vanrolleghem, P.A. (1999). A simplified mixed-culture biofilm model. Wat. Res. 33(9). 2148-2162.

Reichert, P., and Wanner, O. (1997). Movement of solids in biofilms: significance of liquid phase transport. Wat. Sci. Tech. 95(2-3). 289-299.

Reichert, P. (1998). AQUASIM 2.0 - User Manual. ISBN: 3-906484-16-5, Dübendorf, Switzerland.

Rowe, P.N., Claxton, K.T. and Lewis, J.B. (1965) Heat and mass transfer from a single sphere in an extensive flowing fluid. Trans. Inst. Chem. Eng. 43, 14-31.

Rusten, B., Eikebrokk, B., Ulgenes, Y. and Lygren, E. (2006). Design and operations of the Kaldnes moving bed biofilm reactors. Aquacul. Eng. 34(3), 322-331.

Sen, D., and Randall, C. W. (2008) Improved computational model (AQUIFAS) for activated sludge, integrated fixedfilm activated sludge, and moving-bed biofilm reactor systems, part II: multilayer biofilm diffusional model. Wat. Env. Res., 80, 624-632.

Sin, G., Weijma, J., Spanjers, H., and Nopens, I. (2008). Dynamic model development and validation for a nitrifying moving bed biofilter: effect of temperature and influent load on the performance. Process Biochem. 43. 384-397.

Sin, G., Van Hulle, S.W.H., De Pauw, D.J.W., van Griensven, A., and Vanrolleghem, P.A. (2005). A critical comparison of systematic calibration protocols for activated sludge models: A SWOT analysis. Wat. Res. 39. 24592474.

Smets, B.F., Riefler, R.G., Lendenmann, U., Spain, J.C. (1999). Kinetic analysis of simultaneous 2,4-dinitrotoluene (DNT) and 2,6-DNT biodegradation in an aerobic fluidized-bed biofilm reactor. Biotech. Bioeng. 63(6). 642-653.

Stewart, P.S. (2003). Diffusion in biofilms. Guest commentaires. J. Bacteriology. 185(5). 1485-1491.

Takács, I., Bye, C.M., Chapman, K., Dold, P.L., Fairlamb, P.M., Jones, R.M. (2007). A biofilm model for engineering design. Wat. Sci. Tech. 55(8-9). 329-336.

Van Hulle, S.W.H., Maertens, J., De Pauw, D.J.W., Vanrolleghem, P.A. (2004). Using parameter sensitivity analysis of the CANON biofilm process: what to measure, where to measure and under which conditions? Wat. and Envron. Management Series Young Researchers. 59-66.

van Loosdrecht, M.C.M., Eikelboom, D., Gjaltema, A., Mulder, A., Tijhuis, L., and Heijnen, J.J. (1995). Biofilm structures. Wat. Sci. Tech. 32(8). 35-43.

Wanner, O., Eberl, H., Morgenroth, E., Noguera, D., Picioreanu, C., Rittmann, B., and van Loosdrecht, M. (2006). Scientific and Technical Report No. 18, Mathematical Modeling of Biofilms. IWA Publishing, London, UK.

Wanner, O.; Reichert, P. (1996) Mathematical-modeling of mixed-culture biofilms. Biotech. Bioeng., 49 (2), $172-184$.

Zhang, X., and Bishop, P.L. (1994). Evaluation of tortuosity factors and effective diffusivities in biofilm. Wat. Res. 28. 2279-2287. 


\section{APPENDIX A}

Table A1. State variables for the modified ASM3 without storage

\begin{tabular}{|c|c|c|}
\hline Symbol & Description & Unit \\
\hline \multicolumn{3}{|c|}{ Dissolved components: } \\
\hline $\mathrm{S}_{\mathrm{S}}$ & Readily biodegradable substrates & $\mathrm{g} \mathrm{COD} \mathrm{m}^{-3}$ \\
\hline $\mathrm{S}_{\mathrm{I}}$ & Soluble inert organic matter & $\mathrm{g} \mathrm{COD} \mathrm{m}^{-3}$ \\
\hline $\mathrm{S}_{\mathrm{N} 2}$ & Dinitrogen, $\mathrm{N}_{2}$ & $\mathrm{~g} \mathrm{~N} \mathrm{~m}^{-3}$ \\
\hline $\mathrm{S}_{\mathrm{NH} 4}$ & Ammonium plus ammonia nitrogen & $\mathrm{g} \mathrm{N} \mathrm{m}^{-3}$ \\
\hline $\mathrm{S}_{\mathrm{NO} 3}$ & Nitrate plus nitrite nitrogen & $\mathrm{g} \mathrm{N} \mathrm{m}^{-3}$ \\
\hline $\mathrm{S}_{\mathrm{O} 2}$ & Dissolved oxygen & $\mathrm{g} \mathrm{COD} \mathrm{m}^{-3}$ \\
\hline $\mathrm{S}_{\mathrm{ALK}}$ & Alkalinity & mole $\mathrm{HCO}_{3}^{-} \mathrm{L}^{-1}$ \\
\hline$S_{M}$ & Methanol (only denitrification system) & $\mathrm{g} \mathrm{COD} \mathrm{m}^{-3}$ \\
\hline \multicolumn{3}{|c|}{ Particulate components: } \\
\hline $\mathrm{X}_{\mathrm{H}}$ & Heterotrophic organisms & $\mathrm{g} \mathrm{COD} \mathrm{m}^{-3}$ \\
\hline $\mathrm{X}_{\mathrm{I}}$ & Inert particulate organic matter & $\mathrm{g} \mathrm{COD} \mathrm{m}^{-3}$ \\
\hline $\mathrm{X}_{\mathrm{S}}$ & Slowly biodegradable organic substrates & $\mathrm{g} \mathrm{COD} \mathrm{m}^{-3}$ \\
\hline $\mathrm{X}_{\mathrm{A}}$ & Nitrifying organisms & $\mathrm{g} \mathrm{COD} \mathrm{m}^{-3}$ \\
\hline $\mathrm{X}_{\mathrm{TSS}}(*)$ & Total suspended solids & $\mathrm{g} \mathrm{COD} \mathrm{m}^{-3}$ \\
\hline $\mathrm{X}_{\mathrm{M} 1}$ & Methanol degraders 1 (only denitrification system) & $\mathrm{g} \mathrm{COD} \mathrm{m}^{-3}$ \\
\hline $\mathrm{X}_{\mathrm{M} 2}$ & Methanol degraders 2 (only denitrification system) & $\mathrm{g} \mathrm{COD} \mathrm{m}^{-3}$ \\
\hline
\end{tabular}

${ }^{(*)}$ Not introduced as state variable, but calculated from the state variables $\mathrm{X}_{\mathrm{H}}, \mathrm{X}_{\mathrm{A}}, \mathrm{X}_{\mathrm{I}}, \mathrm{X}_{\mathrm{S}}, \mathrm{X}_{\mathrm{M} 1}$, and $\mathrm{X}_{\mathrm{M} 2}$ 
Table A2. Stoichiometric parameter values for the modified ASM3 without storage used in the biofilm simulation benchmark. Unless otherwise noted, values are from Henze et al. (2000).

\begin{tabular}{|c|c|c|c|}
\hline Symbol & Description & Value & Unit \\
\hline \multicolumn{4}{|c|}{ Conversion factors } \\
\hline \multicolumn{4}{|c|}{ Nitrogen: } \\
\hline \multicolumn{4}{|c|}{ Soluble Material } \\
\hline $\mathrm{i}_{\mathrm{NSI}}$ & Nitrogen content of inert soluble COD, $S_{I}$ & 0.01 & $\mathrm{~g} \mathrm{~N} \mathrm{~g}^{-1} \mathrm{COD}$ \\
\hline$i_{N S S}$ & Nitrogen content of readily biodegradable substrate, $\mathrm{S}_{\mathrm{S}}$ & 0.03 & $\mathrm{~g} \mathrm{~N} \mathrm{~g}^{-1} \mathrm{COD}$ \\
\hline \multicolumn{4}{|c|}{ Particulate Material } \\
\hline$i_{\text {NXI }}$ & Nitrogen content of inert particulate COD, $\mathrm{X}_{\mathrm{I}}$ & 0.02 & $\mathrm{~g} \mathrm{~N} \mathrm{~g}^{-1} \mathrm{COD}$ \\
\hline $\mathrm{i}_{\mathrm{NXS}}$ & Nitrogen content of slowly biodegradable substrate, $X_{S}$ & 0.04 & $\mathrm{~g} \mathrm{~N} \mathrm{~g}^{-1} \mathrm{COD}$ \\
\hline $\mathrm{i}_{\mathrm{NBM}}$ & Nitrogen content of biomass, $\mathrm{X}_{\mathrm{H}}, \mathrm{X}_{\mathrm{A}}, \mathrm{X}_{\mathrm{M} 1}, \mathrm{X}_{\mathrm{M} 2}$ & 0.07 & $\mathrm{~g} \mathrm{~N} \mathrm{~g}^{-1} \mathrm{COD}$ \\
\hline \multicolumn{4}{|c|}{ Total Suspended Solids: } \\
\hline $\mathrm{i}_{\text {TSSXI }}$ & TSS to COD ratio for $X_{I}$ & 0.75 & $\mathrm{~g} \mathrm{TSS} \mathrm{g}^{-1} \mathrm{COD}$ \\
\hline$i_{\text {TSSXS }}$ & TSS to COD ratio for $\mathrm{X}_{\mathrm{S}}$ & 0.75 & $\mathrm{~g} \mathrm{TSS} \mathrm{g}^{-1} \mathrm{COD}$ \\
\hline $\mathrm{i}_{\mathrm{TSSBM}}$ & TSS to COD ratio for biomass, $X_{H}, X_{A}, X_{M 1}, X_{M 2}$ & 0.90 & $\mathrm{~g} \mathrm{TSS} \mathrm{g}^{-1} \mathrm{COD}$ \\
\hline \multicolumn{4}{|c|}{ Stoichiometric parameters } \\
\hline \multicolumn{4}{|c|}{ Hydrolysis } \\
\hline$f_{S I}$ & Production of $S_{I}$ in hydrolysis & 0.1 & $\mathrm{~g} \mathrm{COD} \mathrm{g}^{-1} \mathrm{COD}$ \\
\hline \multicolumn{4}{|c|}{ Heterotrophic biomass } \\
\hline $\mathrm{Y}_{\mathrm{H}, \mathrm{O} 2}$ & Yield of heterotrophs using oxygen & 0.63 & $\mathrm{~g} \mathrm{COD} \mathrm{g}^{-1} \mathrm{COD}$ \\
\hline $\mathrm{Y}_{\mathrm{H}, \mathrm{NO}}$ & Yield of heterotrophs using nitrate & 0.54 & $\mathrm{~g} \mathrm{COD} \mathrm{g}^{-1} \mathrm{COD}$ \\
\hline$f_{X I}$ & Production of $X_{I}$ in endogenous respiration & 0.2 & $\mathrm{~g} \mathrm{COD} \mathrm{g}^{-1} \mathrm{COD}$ \\
\hline \multicolumn{4}{|c|}{ Autotrophic biomass } \\
\hline $\mathrm{Y}_{\mathrm{A}}$ & Yield of autotrophs & 0.24 & $\mathrm{~g} \mathrm{COD} \mathrm{g}^{-1} \mathrm{COD}$ \\
\hline$f_{X I}$ & Production of $X_{I}$ in endogenous respiration & 0.2 & $\mathrm{~g} \mathrm{COD} \mathrm{g}^{-1} \mathrm{COD}$ \\
\hline \multicolumn{4}{|c|}{ Methanol degraders 1 (only denitrification system) } \\
\hline $\mathrm{Y}_{\mathrm{M} 1}$ & Yield of methanol degraders type 1 & $0.58^{(*)}$ & $\mathrm{g} \mathrm{COD} \mathrm{g}^{-1} \mathrm{COD}$ \\
\hline$f_{X I}$ & Production of $X_{I}$ in endogenous respiration & 0.2 & $\mathrm{~g} \mathrm{COD} \mathrm{g}^{-1} \mathrm{COD}$ \\
\hline \multicolumn{4}{|c|}{ Methanol degraders 2 (only denitrification system) } \\
\hline $\mathrm{Y}_{\mathrm{M} 2}$ & Yield of methanol degraders type 2 & $0.44^{(*)}$ & $\mathrm{g} \mathrm{COD} \mathrm{g}^{-1} \mathrm{COD}$ \\
\hline$f_{X I}$ & Production of $X_{I}$ in endogenous respiration & 0.2 & $\mathrm{~g} \mathrm{COD} \mathrm{g}^{-1} \mathrm{COD}$ \\
\hline
\end{tabular}

(*) Boltz et al. (2009) 
Table A3. Kinetic parameter values (at $20^{\circ} \mathrm{C}$ ) for the modified ASM3 without storage used in the biofilm simulation benchmark. Unless otherwise noted, values are from Henze et al. (2000).

\begin{tabular}{|c|c|c|c|c|}
\hline Symbol & Description & Value & Unit & $\theta$ \\
\hline \multicolumn{5}{|c|}{ Hydrolysis of particulate substrates: $X_{S}$} \\
\hline $\mathrm{k}_{\mathrm{h}}$ & Hydrolysis rate constant & 3.00 & $\mathrm{~d}^{-1}$ & 1.041 \\
\hline $\mathrm{K}_{\mathrm{X}}$ & Hydrolysis saturation constant & 1.00 & $\mathrm{~g} \mathrm{X}_{\mathrm{S}} \mathrm{g}^{-1} \mathrm{X}_{\mathrm{H}}$ & - \\
\hline \multicolumn{5}{|c|}{ Heterotrophic organisms: $X_{H}$} \\
\hline$\mu_{\mathrm{H}}$ & Maximum growth rate on substrate & 6.00 & $\mathrm{~d}^{-1}$ & 1.072 \\
\hline$\eta_{\mathrm{NO} 3, \mathrm{H}}$ & Reduction factor for denitrification & 0.80 & - & - \\
\hline $\mathrm{b}_{\mathrm{H}, \mathrm{O} 2}$ & Aerobic endogenous respiration rate of $\mathrm{X}_{\mathrm{H}}$ & 0.20 & $\mathrm{~d}^{-1}$ & 1.072 \\
\hline$b_{\mathrm{H}, \mathrm{NO}}$ & Anoxic endogenous respiration rate of $X_{H}$ & 0.10 & $\mathrm{~d}^{-1}$ & 1.072 \\
\hline $\mathrm{K}_{\mathrm{O} 2 \mathrm{H}}$ & Saturation/inhibition coefficient for oxygen & $0.10^{(*)}$ & $\mathrm{g} \mathrm{O}_{2} \mathrm{~m}^{-3}$ & - \\
\hline $\mathrm{K}_{\mathrm{S}}$ & Saturation coefficient for growth on $\mathrm{S}_{\mathrm{S}}$ & $4.00^{(*)}$ & $\mathrm{g} \mathrm{COD} \mathrm{m}^{-3}$ & - \\
\hline $\mathrm{K}_{\mathrm{NO} 3, \mathrm{H}}$ & Saturation/inhibition coefficient for nitrate & $0.14^{(\star \star)}$ & $\mathrm{g} \mathrm{N} \mathrm{m}^{-3}$ & - \\
\hline $\mathrm{K}_{\mathrm{NH} 4, \mathrm{H}}$ & Saturation coefficient for ammonium (nutrient) & 0.01 & $\mathrm{~g} \mathrm{~N} \mathrm{~m}^{-3}$ & - \\
\hline $\mathrm{K}_{\mathrm{ALK}, \mathrm{H}}$ & Saturation coefficient for alkalinity $\left(\mathrm{HCO}_{3}^{-}\right)$ & 0.10 & mole $\mathrm{HCO}_{3}{ }^{-} \mathrm{m}^{-3}$ & - \\
\hline \multicolumn{5}{|c|}{ Nitrifying (autotrophic) organisms: $X_{A}$} \\
\hline$\mu_{\mathrm{A}}$ & Maximum growth rate of $X_{A}$ & 1.00 & $d^{-1}$ & 1.111 \\
\hline $\mathrm{b}_{\mathrm{A}, \mathrm{O} 2}$ & Aerobic endogenous respiration rate of $\mathrm{X}_{\mathrm{A}}$ & 0.15 & $\mathrm{~d}^{-1}$ & 1.116 \\
\hline$b_{\mathrm{A}, \mathrm{NO}}$ & Anoxic endogenous respiration rate of $\mathrm{X}_{\mathrm{A}}$ & 0.05 & $\mathrm{~d}^{-1}$ & 1.116 \\
\hline $\mathrm{K}_{\mathrm{O} 2, \mathrm{~A}}$ & Saturation coefficient for oxygen & $0.80^{(*)}$ & $\mathrm{g} \mathrm{O}_{2} \mathrm{~m}^{-3}$ & - \\
\hline $\mathrm{K}_{\mathrm{NH} 4, \mathrm{~A}}$ & Saturation coefficient for ammonium (substrate) & $0.70^{(* \star)}$ & $\mathrm{g} \mathrm{N} \mathrm{m}^{-3}$ & - \\
\hline $\mathrm{K}_{\mathrm{NO} 3, \mathrm{~A}}$ & Saturation/inhibition coefficient for nitrate & $0.14^{(\star \star \star)}$ & $\mathrm{g} \mathrm{N} \mathrm{m}^{-3}$ & - \\
\hline $\mathrm{K}_{\mathrm{ALK}, \mathrm{A}}$ & Saturation coefficient for alkalinity $\left(\mathrm{HCO}_{3}^{-}\right)$ & $0.40^{(*)}$ & mole $\mathrm{HCO}_{3}{ }^{-} \mathrm{m}^{-3}$ & - \\
\hline \multicolumn{5}{|c|}{ Methanol degraders $1: X_{M I}$ (only denitrification system $)^{(* * * *)}$} \\
\hline$\mu_{\mathrm{M} 1}$ & Maximum growth rate on substrate & 2.56 & $d^{-1}$ & 1.13 \\
\hline$\eta_{\mathrm{NO}, \mathrm{M} 1}$ & Reduction factor for denitrification & 0.20 & - & - \\
\hline $\mathrm{b}_{\mathrm{M} 1}$ & Endogenous respiration rate of $\mathrm{X}_{\mathrm{M} 1}$ & 0.03 & $\mathrm{~d}^{-1}$ & 1.029 \\
\hline $\mathrm{K}_{\mathrm{O} 2, \mathrm{M} 1}$ & Saturation/inhibition coefficient for oxygen & 0.50 & $\mathrm{~g} \mathrm{O}_{2} \mathrm{~m}^{-3}$ & - \\
\hline $\mathrm{K}_{\mathrm{M}, \mathrm{M} 1}$ & Saturation coefficient for growth on $S_{S}$ & 0.50 & $\mathrm{~g} \mathrm{COD} \mathrm{m}^{-3}$ & - \\
\hline $\mathrm{K}_{\mathrm{NO} 3, \mathrm{M} 1}$ & Saturation/inhibition coefficient for nitrate & 0.80 & $\mathrm{~g} \mathrm{~N} \mathrm{~m}^{-3}$ & - \\
\hline $\mathrm{K}_{\mathrm{NH} 4, \mathrm{M} 1}$ & Saturation coefficient for ammonium (nutrient) & 0.005 & $\mathrm{~g} \mathrm{~N} \mathrm{~m}^{-3}$ & - \\
\hline $\mathrm{K}_{\mathrm{ALK}, \mathrm{M} 1}$ & Saturation coefficient for alkalinity $\left(\mathrm{HCO}_{3}^{-}\right)$ & 0.10 & mole $\mathrm{HCO}_{3}^{-} \mathrm{m}^{-3}$ & - \\
\hline \multicolumn{5}{|c|}{ Methanol degraders $2: X_{M 2}$ (only denitrification system $)^{(* * * *)}$} \\
\hline$\mu_{\mathrm{M} 2}$ & Maximum growth rate on substrate & 1.28 & $d^{-1}$ & 1.13 \\
\hline$\eta_{\mathrm{NO} 3, \mathrm{M} 2}$ & Reduction factor for denitrification & 1.00 & - & - \\
\hline$b_{\mathrm{M} 2}$ & Endogenous respiration rate of $\mathrm{X}_{\mathrm{M} 1}$ & 0.03 & $\mathrm{~d}^{-1}$ & 1.029 \\
\hline $\mathrm{K}_{\mathrm{O} 2, \mathrm{M} 2}$ & Saturation/inhibition coefficient for oxygen & 0.50 & $\mathrm{~g} \mathrm{O}_{2} \mathrm{~m}^{-3}$ & - \\
\hline $\mathrm{K}_{\mathrm{M}, \mathrm{M} 2}$ & Saturation coefficient for growth on $\mathrm{S}_{\mathrm{S}}$ & 0.50 & $\mathrm{~g} \mathrm{COD} \mathrm{m}^{-3}$ & - \\
\hline $\mathrm{K}_{\mathrm{NO} 3, \mathrm{M} 2}$ & Saturation/inhibition coefficient for nitrate & 0.10 & $\mathrm{~g} \mathrm{~N} \mathrm{~m}^{-3}$ & - \\
\hline $\mathrm{K}_{\mathrm{NH} 4, \mathrm{M} 2}$ & Saturation coefficient for ammonium (nutrient) & 0.005 & $\mathrm{~g} \mathrm{~N} \mathrm{~m}^{-3}$ & - \\
\hline $\mathrm{K}_{\mathrm{ALK}, \mathrm{M} 2}$ & Saturation coefficient for alkalinity $\left(\mathrm{HCO}_{3}^{-}\right)$ & 0.10 & mole $\mathrm{HCO}_{3}{ }^{-} \mathrm{m}^{-3}$ & - \\
\hline
\end{tabular}


Table A4. Biofilm parameters and diffusion coefficients

\begin{tabular}{|c|c|c|c|}
\hline Symbol & Description & Value & Unit \\
\hline \multicolumn{4}{|c|}{ Diffusion coefficients in water } \\
\hline $\mathrm{D}_{\mathrm{S}}$ & Readily biodegradable substrate & $1.0 \times 10^{-4}$ & $m^{2} d^{-1}$ \\
\hline $\mathrm{D}_{\mathrm{O} 2}$ & Oxygen & $2.1 \times 10^{-4}$ & $m^{2} d^{-1}$ \\
\hline $\mathrm{D}_{\mathrm{NH} 4}$ & Ammonium & $1.7 \times 10^{-4}$ & $m^{2} d^{-1}$ \\
\hline $\mathrm{D}_{\mathrm{NO} 3}$ & Nitrate & $1.6 \times 10^{-4}$ & $m^{2} d^{-1}$ \\
\hline $\mathrm{D}_{\mathrm{N} 2}$ & Dinitrogen & $2.1 \times 10^{-4}$ & $m^{2} d^{-1}$ \\
\hline $\mathrm{D}_{\mathrm{ALK}}$ & Alkalinity & $1.0 \times 10^{-4}$ & $\mathrm{~m}^{2} \mathrm{~d}^{-1}$ \\
\hline $\mathrm{D}_{\mathrm{SI}}$ & Soluble inerts & $1.0 \times 10^{-4}$ & $m^{2} d^{-1}$ \\
\hline $\mathrm{D}_{\mathrm{Xs}}$ & Slowly biodegradable substrate & $0.6 \times 10^{-4}(*)$ & $m^{2} d^{-1}$ \\
\hline $\mathrm{D}_{\mathrm{M}}$ & Methanol (only denitrification system) & $1.5 \times 10^{-4}$ & $m^{2} d^{-1}$ \\
\hline \multicolumn{4}{|c|}{ Biofilm parameters } \\
\hline $\mathrm{D}_{\mathrm{F}} / \mathrm{D}$ & Ratio of diffusion in biofilm to diffusion in water & 0.8 & - \\
\hline$\varepsilon_{1}$ & Fraction of the liquid volume in the biofilm & 0.8 & - \\
\hline $\mathrm{X}_{\mathrm{F}, \text { tot }}$ & Biofilm density & 25000 & $\mathrm{~g} \mathrm{COD}_{\mathrm{X}} / \mathrm{m}^{3}$ \\
\hline$\rho_{\mathrm{X}}$ & Biomass density in the biofilm $\left(\mathrm{X}_{\mathrm{F}, \text { tot }} /\left(1-\varepsilon_{1}\right)\right)$ & 125000 & $\mathrm{~g} \mathrm{COD}_{\mathrm{X}} / \mathrm{m}^{3}$ \\
\hline $\mathrm{L}_{\mathrm{F}, \text { tot }}$ & Biofilm thickness & 200 & $\mu \mathrm{m}$ \\
\hline $\mathrm{L}_{\mathrm{L}}$ & External mass transfer layer thickness & 100 & $\mu \mathrm{m}$ \\
\hline
\end{tabular}

Temperature dependency of diffusion coefficients was accounted for according to:

$$
D(T)=D\left(20^{\circ} C\right) \cdot \frac{273+T}{273+20^{\circ} C} \cdot \frac{\mu\left(20^{\circ} C\right)}{\mu(T)}
$$

where $\mathrm{D}$ is the diffusion coefficient, $\mathrm{T}$ the temperature in ${ }^{\circ} \mathrm{C}$, and $\mu$ the dynamic viscosity of water in $\mathrm{N} \mathrm{m}^{-2} \mathrm{~s}$.

The MTBL thickness, $L_{L}$, was estimated from fluid dynamics using a method similar to the one described by Morgenroth (2008):

$$
L_{L}=\frac{L_{c}}{S h}
$$

where $L_{c}$ is a characteristic length (which in this case is the flow-through radius of the biofilm carrier minus the biofilm thickness; the biofilm carrier flow through radius is $0.00455 \mathrm{~m}$ in Veolia AnoxKaldness Process K1 medium (Veolia, Paris, France) according to Rusten et al. (2006), and Sh is the non-dimensional Sherwood number. The following empirical correlation described by Rowe et al. (1965) was used to calculate the Sherwood number:

$$
S h=A+B \cdot R e^{m} \cdot S c^{n}
$$

The following empirical parameter values and relationships were applied to estimate $L_{L}$.

$A \quad=2.0$ (value by Rowe et al. (1965) for spherical particles)

$B \quad=0.8$ (value by Rowe et al. (1965) for spherical particles) 


$$
\begin{array}{ll}
m & =1 / 2 \text { (value by Rowe et al. }(1965) \text { for spherical particles) } \\
n & =1 / 3 \text { (value by Rowe } \text { et al. }(1965) \text { for spherical particles) } \\
R e & =\text { Reynolds number }=\left(U \cdot L_{c}\right) / v \\
U & =\text { water velocity in vicinity of biofilm surface } \sim 5000 \mathrm{~m} / \mathrm{d} \text { (Boltz } \text { et al. } 2009) \\
v & =\text { kinematic viscosity of water }=1.0 \times 10^{-6} \mathrm{~m}^{2} / \mathrm{s} \\
S c & =\text { Schmidt number }=v / D_{W, i} \\
D_{W, i} & =\text { diffusion coefficient of substance } \mathrm{i} \text { in water }\left(\mathrm{m}^{2} / \mathrm{d}\right)
\end{array}
$$


Table A5. Process rate equations for the modified ASM3 without storage as used in the biofilm simulation benchmark (Henze et al., 2000).

Process

Process rate equation

Hydrolysis processes:

1 Aerobic hydrolysis

$$
k_{h} \cdot \frac{X_{S} / X_{H}}{K_{X}+X_{S} / X_{H}} \cdot X_{H}
$$

Heterotrophic organisms: $\mathrm{X}_{\mathrm{H}}$

2 Aerobic growth of $X_{H}$

$$
\mu_{H} \cdot \frac{S_{O 2}}{K_{O 2, H}+S_{O 2}} \cdot \frac{S_{S}}{K_{S}+S_{S}} \cdot \frac{S_{N H 4}}{K_{N H 4, H}+S_{N H 4}} \cdot \frac{S_{A L K}}{K_{A L K, H}+S_{A L K}} \cdot X_{H}
$$

3 Anoxic growth of $\mathrm{X}_{\mathrm{H}}$

$$
\mu_{H} \cdot \eta_{N O 3, H} \cdot \frac{K_{O 2, H}}{K_{O 2, H}+S_{O 2}} \cdot \frac{S_{N O 3}}{K_{N O 3, H}+S_{N O 3}} \cdot \frac{S_{S}}{K_{S}+S_{S}} \cdot \frac{S_{N H 4}}{K_{N H 4, H}+S_{N H 4}} \cdot \frac{S_{A L K}}{K_{A L K, H}+S_{A L K}} \cdot X_{H}
$$

4 Aerobic end. respiration of $\mathrm{X}_{\mathrm{H}}$

$$
b_{H, O 2} \cdot \frac{S_{O 2}}{K_{O 2, H}+S_{O 2}} \cdot X_{H}
$$

5 Anoxic end. respiration of $\mathrm{X}_{\mathrm{H}}$

$$
b_{H, N O} \cdot \frac{K_{O 2, H}}{K_{O 2, H}+S_{O 2}} \cdot \frac{S_{N O 3}}{K_{N O 3, H}+S_{N O 3}} \cdot X_{H}
$$

Nitrifying organisms: $\mathrm{X}_{\mathrm{A}}$

6 Aerobic growth of $\mathrm{X}_{\mathrm{A}}$

$$
\mu_{A} \cdot \frac{S_{O 2}}{K_{O 2, A}+S_{O 2}} \cdot \frac{S_{N H 4}}{K_{N H 4, H}+S_{N H 4}} \cdot \frac{S_{A L K}}{K_{A L K, A}+S_{A L K}} \cdot X_{A}
$$

7 Aerobic end. respiration of $\mathrm{X}_{\mathrm{A}}$

$$
b_{A, O 2} \cdot \frac{S_{O 2}}{K_{O 2, A}+S_{O 2}} \cdot X_{A}
$$

8 Anoxic end. respiration of $\mathrm{X}_{\mathrm{A}}$

$$
b_{A, N O} \cdot \frac{K_{O 2, H}}{K_{O 2, A}+S_{O 2}} \cdot \frac{S_{N O 3}}{K_{N O 3, A}+S_{N O 3}} \cdot X_{A}
$$

Methylotrophs 1: $\mathrm{X}_{\mathrm{M} 1}$ (only denitrification system)

9 Aerobic growth of $X_{\mathrm{M} 1}$

10 Anoxic growth of $X_{M 1}$

11 Aerobic end. respiration of $\mathrm{X}_{\mathrm{M} 1} \quad b_{M 1} \cdot \frac{S_{O 2}}{K_{O 2, M 1}+S_{O 2}} \cdot X_{M 1}$

12 Anoxic end. respiration of $\mathrm{X}_{\mathrm{M} 1}$

$$
\mu_{M 1} \cdot \frac{S_{O 2}}{K_{O 2, M 1}+S_{O 2}} \cdot \frac{S_{M}}{K_{M 1}+S_{M}} \cdot \frac{S_{N H 4}}{K_{N H 4, M 1}+S_{N H 4}} \cdot \frac{S_{A L K}}{K_{A L K, M 1}+S_{A L K}} \cdot X_{M 1}
$$$$
\mu_{M 1} \cdot \eta_{N O 3, M 1} \cdot \frac{K_{O 2, M 1}}{K_{O 2, M 1}+S_{O 2}} \cdot \frac{S_{N O 3}}{K_{N O 3, M 1}+S_{N O 3}} \cdot \frac{S_{M}}{K_{M 1}+S_{M}} \cdot \frac{S_{N H 4}}{K_{N H 4, M 1}+S_{N H 4}} \cdot \frac{S_{A L K}}{K_{A L K, M 1}+S_{A L K}} \cdot X_{M 1}
$$

$$
b_{M 1} \cdot \frac{K_{O 2, M 1}}{K_{O 2, M 1}+S_{O 2}} \cdot \frac{S_{N O 3}}{K_{N O 3, M 1}+S_{N O 3}} \cdot X_{M 1}
$$

Methylotrophs 2: $\mathrm{X}_{\mathrm{M} 2}$ (only denitrification system)

13 Aerobic growth of $X_{\mathrm{M} 2}$

14 Anoxic growth of $\mathrm{X}_{\mathrm{M} 2}$

15 Aerobic end. respiration of $\mathrm{X}_{\mathrm{M} 2}$

16 Anoxic end. respiration of $\mathrm{X}_{\mathrm{M} 2}$
$\mu_{M 2} \cdot \frac{S_{O 2}}{K_{O 2, M 2}+S_{O 2}} \cdot \frac{S_{M}}{K_{M 2}+S_{M}} \cdot \frac{S_{N H 4}}{K_{N H 4, M 2}+S_{N H 4}} \cdot \frac{S_{A L K}}{K_{A L K, M 2}+S_{A L K}} \cdot X_{M 2}$

$\mu_{M 2} \cdot \eta_{N O 3, M 2} \cdot \frac{K_{O 2, M 2}}{K_{O 2, M 2}+S_{O 2}} \cdot \frac{S_{N O 3}}{K_{N O 3, M 2}+S_{N O 3}} \cdot \frac{S_{M}}{K_{M 2}+S_{M}} \cdot \frac{S_{N H 4}}{K_{N H 4, M 2}+S_{N H 4}} \cdot \frac{S_{A L K}}{K_{A L K, M 2}+S_{A L K}} \cdot X_{M 2}$

$b_{M 2} \cdot \frac{S_{O 2}}{K_{O 2, M 2}+S_{O 2}} \cdot X_{M 2}$

$b_{M 2} \cdot \frac{K_{O 2, M 2}}{K_{O 2, M 2}+S_{O 2}} \cdot \frac{S_{N O 3}}{K_{N O 3, M 2}+S_{N O 3}} \cdot X_{M 2}$ 
Table A6. Stoichiometric matrix of soluble state variables for the modified ASM3 without storage as used in the biofilm simulation benchmark (Henze et al., 2000).

\begin{tabular}{|c|c|c|c|c|c|c|c|c|}
\hline Process & $\mathrm{S}_{\mathrm{O} 2}$ & $\mathrm{~S}_{\mathrm{S}}$ & $\mathrm{S}_{\mathrm{I}}$ & $\mathrm{S}_{\mathrm{NH} 4}$ & $\mathrm{~S}_{\mathrm{NO} 3}$ & $\mathrm{~S}_{\mathrm{N} 2}$ & $\mathrm{~S}_{\mathrm{ALK}}$ & $S_{M}$ \\
\hline \multicolumn{9}{|l|}{ Hydrolysis processes: } \\
\hline 1 Aerobic hydrolysis & & $1-f_{S I}$ & $\mathrm{f}_{\mathrm{SI}}$ & $v_{1, \mathrm{NH} 4}$ & & & $v_{1, \mathrm{ALK}}$ & \\
\hline \multicolumn{9}{|l|}{ Heterotrophic organisms: $X_{H}$} \\
\hline 2 Aerobic growth of $X_{H}$ & $\begin{array}{c}-\left(1-\mathrm{Y}_{\mathrm{H}, \mathrm{O} 2}\right) / \\
\mathrm{Y}_{\mathrm{H}, \mathrm{O} 2}\end{array}$ & $-1 / \mathrm{Y}_{\mathrm{H}, 02}$ & & $v_{2, \mathrm{NH} 4}$ & & & $v_{2, \mathrm{ALK}}$ & \\
\hline 3 Anoxic growth of $X_{H}$ & & $\overline{-}_{1 / \mathrm{Y}_{\mathrm{H}, \mathrm{NO}}}$ & & $v_{3, \mathrm{NH} 4}$ & $\begin{array}{c}-\left(1-\mathrm{Y}_{\mathrm{H}, \mathrm{NO}}\right) / \\
\left(2.86 \cdot \mathrm{Y}_{\mathrm{H}, \mathrm{NO}}\right)\end{array}$ & $\begin{array}{c}\left(1-\mathrm{Y}_{\mathrm{H}, \mathrm{NO}}\right) / \\
\left(2.86 \cdot \mathrm{Y}_{\mathrm{H}, \mathrm{NO}}\right)\end{array}$ & $v_{3, \mathrm{ALK}}$ & \\
\hline 4 Aerobic end. respiration of $X_{H}$ & $-\left(1-f_{X I}\right)$ & & & $v_{4, \mathrm{NH} 4}$ & & & $v_{4, \mathrm{ALK}}$ & \\
\hline 5 Anoxic end. respiration of $X_{H}$ & & & & $v_{5, \mathrm{NH} 4}$ & $-\left(1-\mathrm{f}_{\mathrm{XI}}\right) / 2.86$ & $\left(1-\mathrm{f}_{\mathrm{XI}}\right) / 2.86$ & $v_{5, \mathrm{ALK}}$ & \\
\hline \multicolumn{9}{|l|}{ Nitrifying organisms: $X_{A}$} \\
\hline 6 Aerobic growth of $X_{A}$ & $\begin{array}{c}-\left(4.57-\mathrm{Y}_{\mathrm{A}}\right) / \\
\mathrm{Y}_{\mathrm{A}}\end{array}$ & & & $v_{6, \mathrm{NH} 4}$ & $1 / \mathrm{Y}_{\mathrm{A}}$ & & $v_{6, \mathrm{ALK}}$ & \\
\hline 7 Aerobic end. respiration of $X_{A}$ & $-\left(1-f_{X I}\right)$ & & & $v_{7, \mathrm{NH} 4}$ & & & $v_{7, \mathrm{ALK}}$ & \\
\hline 8 Anoxic end. respiration of $X_{A}$ & & & & $v_{8, \mathrm{NH} 4}$ & $-\left(1-\mathrm{f}_{\mathrm{XI}}\right) / 2.86$ & $\left(1-\mathrm{f}_{\mathrm{XI}}\right) / 2.86$ & $v_{8, \mathrm{ALK}}$ & \\
\hline \multicolumn{9}{|l|}{ Methylotrophs 1: $\mathrm{X}_{\mathrm{M} 1}$} \\
\hline 9 Aerobic growth of $X_{\mathrm{M} 1}$ & $\begin{array}{c}-\left(1-\mathrm{Y}_{\mathrm{M} 1}\right) / \\
\mathrm{Y}_{\mathrm{M} 1}\end{array}$ & & & $v_{9, \mathrm{NH} 4}$ & & & $v_{9, \mathrm{ALK}}$ & $-1 / \mathrm{Y}_{\mathrm{M} 1}$ \\
\hline 10 Anoxic growth of $\mathrm{X}_{\mathrm{M} 1}$ & & & & $v_{10, \mathrm{NH} 4}$ & $\begin{array}{c}\left(1-\mathrm{Y}_{\mathrm{M} 1}\right) / \\
\left(2.86 \cdot \mathrm{Y}_{\mathrm{M} 1}\right)\end{array}$ & $\begin{array}{c}-\left(1-\mathrm{Y}_{\mathrm{M} 1}\right) / \\
\left(2.86 \cdot \mathrm{Y}_{\mathrm{M} 1}\right)\end{array}$ & $v_{10, \mathrm{ALK}}$ & $-1 / \mathrm{Y}_{\mathrm{M} 1}$ \\
\hline 11 Aerobic end. respiration of $X_{\mathrm{M} 1}$ & $-\left(1-f_{X I}\right)$ & & & $v_{11, \mathrm{NH} 4}$ & & & $v_{11, \mathrm{ALK}}$ & \\
\hline 12 Anoxic end. respiration of $X_{M 1}$ & & & & $v_{12, \mathrm{NH} 4}$ & $-\left(1-\mathrm{f}_{\mathrm{XI}}\right) / 2.86$ & $\left(1-\mathrm{f}_{\mathrm{XI}}\right) / 2.86$ & $v_{12, \mathrm{ALK}}$ & \\
\hline \multicolumn{9}{|l|}{ Methylotrophs 2: $\mathrm{X}_{\mathrm{M} 2}$} \\
\hline 13 Aerobic growth of $X_{M 2}$ & $\begin{array}{c}-\left(1-\mathrm{Y}_{\mathrm{M} 2}\right) / \\
\mathrm{Y}_{\mathrm{M} 2}\end{array}$ & & & $v_{13, \mathrm{NH} 4}$ & & & $v_{13, \mathrm{ALK}}$ & $-1 / \mathrm{Y}_{\mathrm{M} 2}$ \\
\hline 14 Anoxic growth of $X_{\mathrm{M} 2}$ & & & & $v_{14, \mathrm{NH} 4}$ & $\begin{array}{c}\left(1-\mathrm{Y}_{\mathrm{M} 2}\right) / \\
\left(2.86 \cdot \mathrm{Y}_{\mathrm{M} 2}\right)\end{array}$ & $\begin{array}{l}-\left(1-\mathrm{Y}_{\mathrm{M} 2}\right) / \\
\left(2.86 \cdot \mathrm{Y}_{\mathrm{M} 2}\right)\end{array}$ & $v_{14, \mathrm{ALK}}$ & $-1 / Y_{M} 2$ \\
\hline 15 Aerobic end. respiration of $X_{\mathrm{M} 2}$ & $-\left(1-f_{X I}\right)$ & & & $v_{15, \mathrm{NH} 4}$ & & & $v_{15, \mathrm{ALK}}$ & \\
\hline 16 Anoxic end. respiration of $X_{\mathrm{M} 2}$ & & & & $v_{16, \mathrm{NH} 4}$ & $-\left(1-\mathrm{f}_{\mathrm{XI}}\right) / 2.86$ & $\left(1-\mathrm{f}_{\mathrm{XI}}\right) / 2.86$ & $v_{16, \mathrm{ALK}}$ & \\
\hline
\end{tabular}


Table A7. Stoichiometric matrix of particulate state variables for the modified ASM3 without storage as used in the biofilm simulation benchmark (Henze et al., 2000).

\begin{tabular}{|c|c|c|c|c|c|c|}
\hline Process & $\mathrm{X}_{\mathrm{S}}$ & $\mathrm{X}_{\mathrm{H}}$ & $\mathrm{X}_{\mathrm{A}}$ & $\mathrm{X}_{\mathrm{I}}$ & $\mathrm{X}_{\mathrm{M} 1}$ & $\mathrm{X}_{\mathrm{M} 2}$ \\
\hline \multicolumn{7}{|l|}{ Hydrolysis processes: } \\
\hline 1 Aerobic hydrolysis & -1 & & & & & \\
\hline \multicolumn{7}{|l|}{ Heterotrophic organisms: $X_{H}$} \\
\hline 2 Aerobic growth of $X_{H}$ & & 1 & & & & \\
\hline 3 Anoxic growth of $X_{H}$ & & 1 & & & & \\
\hline 4 Aerobic end. respiration of $X_{H}$ & & -1 & & $\mathrm{f}_{\mathrm{XI}}$ & & \\
\hline 5 Anoxic end. respiration of $X_{H}$ & & -1 & & $f_{X I}$ & & \\
\hline \multicolumn{7}{|l|}{ Nitrifying organisms: $X_{A}$} \\
\hline 6 Aerobic growth of $X_{A}$ & & & 1 & & & \\
\hline 7 Aerobic end. respiration of $X_{A}$ & & & -1 & $\mathrm{f}_{\mathrm{XI}}$ & & \\
\hline 8 Anoxic end. respiration of $X_{A}$ & & & -1 & $\mathrm{f}_{\mathrm{XI}}$ & & \\
\hline \multicolumn{7}{|l|}{ Methylotrophs 1: $\mathrm{X}_{\mathrm{M} 1}$} \\
\hline 9 Aerobic growth of $X_{M 1}$ & & & & & 1 & \\
\hline 10 Anoxic growth of $X_{M 1}$ & & & & & 1 & \\
\hline 11 Aerobic end. respiration of $X_{M 1}$ & & & & $f_{X I}$ & -1 & \\
\hline 12 Anoxic end. respiration of $X_{\mathrm{M} 1}$ & & & & $\mathrm{f}_{\mathrm{XI}}$ & -1 & \\
\hline \multicolumn{7}{|l|}{ Methylotrophs 2: $\mathrm{X}_{\mathrm{M} 2}$} \\
\hline 13 Aerobic growth of $X_{\mathrm{M} 2}$ & & & & & & 1 \\
\hline 14 Anoxic growth of $X_{M 2}$ & & & & & & 1 \\
\hline 15 Aerobic end. respiration of $X_{\mathrm{M} 2}$ & & & & $f_{X I}$ & & -1 \\
\hline 16 Anoxic end. respiration of $X_{\mathrm{M} 2}$ & & & & $f_{X I}$ & & -1 \\
\hline
\end{tabular}

$\mathrm{X}_{\mathrm{TSS}}$ was calculated from the particulate state variables:

$X_{T S S, \text { bulk }}=X_{\text {TSS, inorganic, in }}+i_{T S B M} \cdot\left(X_{A, \text { bulk }}+X_{H, \text { bulk }}+X_{M 1, \text { bulk }}+X_{M 2, \text { bulk }}\right)+i_{T S X S} \cdot X_{S, \text { bulk }}+i_{T S X I} \cdot X_{I, \text { bulk }}$

$X_{T S S, \text { biofilm }}=i_{T S B M} \cdot\left(X_{A, \text { bifflm }}+X_{H, \text { bifflm }}+X_{M I, \text { bulk }}+X_{M 2, \text { bulk }}\right)+i_{T S X S} \cdot X_{S, \text { bioflim }}+i_{T S X I} \cdot X_{I, \text { bioflim }}$

where $X_{\text {TSS,inorganic,in }}$ is the amount of total suspended solids that is not account for by influent concentrations of $\mathrm{X}_{\mathrm{S}}, \mathrm{X}_{\mathrm{H}}, \mathrm{X}_{\mathrm{A}}, \mathrm{X}_{\mathrm{M} 1}, \mathrm{X}_{\mathrm{M} 2}$, and $\mathrm{X}_{\mathrm{I}}$. 
Table A8. Stoichiometric coefficients for $\mathrm{S}_{\mathrm{NH} 4}$ and $\mathrm{S}_{\mathrm{ALK}}$

\begin{tabular}{|c|c|c|}
\hline Process & $\mathrm{S}_{\mathrm{NH} 4}$ & $\mathrm{~S}_{\mathrm{ALK}}$ \\
\hline \multicolumn{3}{|l|}{ Hydrolysis processes: } \\
\hline 1 Aerobic hydrolysis & $v_{1, N H 4}=i_{N, X S}-\left(1-f_{S I}\right) \cdot i_{N, S S}-f_{S I} \cdot i_{N, S I}$ & $v_{1, A L K}=\left(i_{N, X S}-\left(1-f_{S I}\right) \cdot i_{N, S S}+f_{S I} \cdot i_{N, S I}\right) / 14$ \\
\hline \multicolumn{3}{|l|}{ Heterotrophic organisms: $\mathrm{X}_{\mathrm{H}}$} \\
\hline 2 Aerobic growth of $X_{H}$ & $v_{2, N H 4}=-i_{N, B M}$ & $v_{2, A L K}=-i_{N, B M} / 14$ \\
\hline 3 Anoxic growth of $X_{H}$ & $v_{3, N H 4}=-i_{N, B M}$ & $v_{3, A L K}=\left(-i_{N, B M}+\left(1-Y_{H, N O}\right) /\left(2.86 \cdot Y_{H, N O}\right)\right) / 14$ \\
\hline 4 Aerobic end. respiration of $X_{H}$ & $v_{4, N H 4}=i_{N, B M}-f_{X I} \cdot i_{N, X I}$ & $v_{4, A L K}=\left(i_{N, B M}-f_{X I} \cdot i_{N, X I}\right) / 14$ \\
\hline 5 Anoxic end. respiration of $X_{H}$ & $v_{5, N H 4}=i_{N, B M}-f_{X I} \cdot i_{N, X I}$ & $v_{5, A L K}=\left(i_{N, B M}-f_{X I} \cdot i_{N, X I}+\left(1-f_{X I}\right) / 2.86\right) / 14$ \\
\hline \multicolumn{3}{|l|}{ Nitrifying organisms: $\mathrm{X}_{\mathrm{A}}$} \\
\hline 6 Aerobic growth of $X_{A}$ & $v_{6, N H 4}=-1 / Y_{A}-i_{N, B M}$ & $v_{6, A L K}=\left(-1 / Y_{A}-i_{N, B M}-1 / Y_{A}\right) / 14$ \\
\hline 7 Aerobic end. respiration of $X_{A}$ & $v_{7, N H 4}=i_{N, B M}-f_{X I} \cdot i_{N, X I}$ & $v_{7, A L K}=\left(i_{N, B M}-f_{X I} \cdot i_{N, X I}\right) / 14$ \\
\hline 8 Anoxic end. respiration of $X_{A}$ & $v_{8, N H 4}=i_{N, B M}-f_{X I} \cdot i_{N, X I}$ & $v_{8, A L K}=\left(i_{N, B M}-f_{X I} \cdot i_{N, X I}+\left(1-f_{X I}\right) / 2.86\right) / 14$ \\
\hline \multicolumn{3}{|l|}{ Methylotrophs 1: $\mathrm{X}_{\mathrm{M} 1}$} \\
\hline 9 Aerobic growth of $X_{\mathrm{M} 1}$ & $v_{9, N H 4}=-i_{N, B M}$ & $v_{9, A L K}=-i_{N, B M} / 14$ \\
\hline 10 Anoxic growth of $X_{M 1}$ & $v_{10, N H 4}=-i_{N, B M}$ & $v_{10, A L K}=\left(-i_{N, B M}+\left(1-Y_{M 1}\right) /\left(2.86 \cdot Y_{M 1}\right)\right) / 14$ \\
\hline 11 Aerobic end. respiration of $\mathrm{X}_{\mathrm{M} 1}$ & $v_{11, N H 4}=i_{N, B M}-f_{X I} \cdot i_{N, X I}$ & $v_{11, A L K}=\left(i_{N, B M}-f_{X I} \cdot i_{N, X I}\right) / 14$ \\
\hline 12 Anoxic end. respiration of $\mathrm{X}_{\mathrm{M} 1}$ & $v_{12, N H 4}=i_{N, B M}-f_{X I} \cdot i_{N, X I}$ & $v_{12, A L K}=\left(i_{N, B M}-f_{X I} \cdot i_{N, X I}+\left(1-f_{X I}\right) / 2.86\right) / 14$ \\
\hline \multicolumn{3}{|l|}{ Methylotrophs 2: $\mathrm{X}_{\mathrm{M} 2}$} \\
\hline 13 Aerobic growth of $X_{M 2}$ & $v_{13, N H 4}=-i_{N, B M}$ & $v_{13, A L K}=-i_{N, B M} / 14$ \\
\hline 14 Anoxic growth of $X_{\mathrm{M} 2}$ & $v_{14, N H 4}=-i_{N, B M}$ & $v_{14, A L K}=\left(-i_{N, B M}+\left(1-Y_{M 1}\right) /\left(2.86 \cdot Y_{M 1}\right)\right) / 14$ \\
\hline 15 Aerobic end. respiration of $X_{\mathrm{M} 2}$ & $v_{15, N H 4}=i_{N, B M}-f_{X I} \cdot i_{N, X I}$ & $v_{15, A L K}=\left(i_{N, B M}-f_{X I} \cdot i_{N, X I}\right) / 14$ \\
\hline 16 Anoxic end. respiration of $X_{\mathrm{M} 2}$ & $v_{16, N H 4}=i_{N, B M}-f_{X I} \cdot i_{N, X I}$ & $v_{16, A L K}=\left(i_{N, B M}-f_{X I} \cdot i_{N, X I}+\left(1-f_{X I}\right) / 2.86\right) / 14$ \\
\hline
\end{tabular}


Table A9. Parameter values and uncertainty ranges used for local sensitivity analysis. The concept of defining uncertainty classes for biokinetic parameters was based on Brun et al. (2002).

\begin{tabular}{|c|c|c|c|c|}
\hline Parameter & Unit & Value & Uncertainty range & Uncertainty class \\
\hline$\mu_{\mathrm{A}}$ & $\mathrm{d}^{-1}$ & 1 & 0.2 & 2 \\
\hline$\mu_{\mathrm{H}}$ & $\mathrm{d}^{-1}$ & 6 & 3 & 3 \\
\hline$\mu_{\mathrm{M} 1}$ & $\mathrm{~d}^{-1}$ & 2.56 & 1.28 & 3 \\
\hline$\mu_{\mathrm{M} 2}$ & $\mathrm{~d}^{-1}$ & 1.28 & 0.64 & 3 \\
\hline $\mathrm{k}_{\mathrm{H}}$ & $\mathrm{d}^{-1}$ & 3 & 1.5 & 3 \\
\hline $\mathrm{K}_{\mathrm{S}, \mathrm{H}}$ & $\mathrm{g} \mathrm{COD} \mathrm{m}^{-3}$ & 4 & 2 & 3 \\
\hline $\mathrm{K}_{\mathrm{M} 1}$ & $\mathrm{~g} \mathrm{COD} \mathrm{m}^{-3}$ & 0.5 & 0.25 & 3 \\
\hline $\mathrm{K}_{\mathrm{M} 2}$ & $\mathrm{~g} \mathrm{COD} \mathrm{m}^{-3}$ & 0.5 & 0.25 & 3 \\
\hline $\mathrm{K}_{\mathrm{NH} 4, \mathrm{~A}}$ & $\mathrm{~g} \mathrm{~N} \mathrm{~m}^{-3}$ & 0.7 & 0.35 & 3 \\
\hline $\mathrm{K}_{\mathrm{NO} 3, \mathrm{H}}$ & $\mathrm{g} \mathrm{N} \mathrm{m}^{-3}$ & 0.14 & 0.028 & 2 \\
\hline $\mathrm{K}_{\mathrm{NO} 3, \mathrm{M} 1}$ & $\mathrm{~g} \mathrm{~N} \mathrm{~m}^{-3}$ & 0.8 & 0.4 & 3 \\
\hline $\mathrm{K}_{\mathrm{NO} 3, \mathrm{M} 2}$ & $\mathrm{~g} \mathrm{~N} \mathrm{~m}^{-3}$ & 0.1 & 0.05 & 3 \\
\hline $\mathrm{K}_{\mathrm{O} 2, \mathrm{~A}}$ & $\mathrm{~g} \mathrm{O}_{2} \mathrm{~m}^{-3}$ & 0.8 & 0.4 & 3 \\
\hline $\mathrm{K}_{\mathrm{O} 2 \mathrm{H}}$ & $\mathrm{g} \mathrm{O}_{2} \mathrm{~m}^{-3}$ & 0.1 & 0.05 & 3 \\
\hline $\mathrm{K}_{\mathrm{X}}$ & $\mathrm{g} \mathrm{X}_{\mathrm{S}} \mathrm{g}^{-1} X_{\mathrm{H}}$ & 1 & 0.5 & 3 \\
\hline $\mathrm{L}_{\mathrm{F}, \text { tot }}$ & $\mu \mathrm{m}$ & 200 & 100 & 3 \\
\hline $\mathrm{X}_{\mathrm{F}, \text { tot }}$ & $\mathrm{g} \mathrm{COD}_{\mathrm{X}} / \mathrm{m}^{3}$ & 25000 & 5000 & 2 \\
\hline $\mathrm{L}_{\mathrm{L}}$ & $\mu \mathrm{m}$ & 100 & 50 & 3 \\
\hline$\varepsilon_{\text {liquid }}$ & - & 0.8 & 0.16 & 2 \\
\hline $\mathrm{D}_{\mathrm{S}}$ & $\mathrm{m}^{2} \mathrm{~d}^{-1}$ & $1.0 \times 10^{-4}$ & $0.2 \times 10^{-4}$ & 2 \\
\hline $\mathrm{D}_{\mathrm{NH} 4}$ & $\mathrm{~m}^{2} \mathrm{~d}^{-1}$ & $1.7 \times 10^{-4}$ & $0.34 \times 10^{-4}$ & 2 \\
\hline $\mathrm{D}_{\mathrm{NO} 3}$ & $\mathrm{~m}^{2} \mathrm{~d}^{-1}$ & $1.6 \times 10^{-4}$ & $0.32 \times 10^{-4}$ & 2 \\
\hline $\mathrm{D}_{\mathrm{O} 2}$ & $m^{2} d^{-1}$ & $2.1 \times 10^{-4}$ & $0.42 \times 10^{-4}$ & 2 \\
\hline $\mathrm{D}_{\mathrm{XS}}$ & $\mathrm{m}^{2} \mathrm{~d}^{-1}$ & $0.6 \times 10^{-4}$ & $0.12 \times 10^{-4}$ & 2 \\
\hline $\mathrm{D}_{\mathrm{ALK}}$ & $m^{2} d^{-1}$ & $1.0 \times 10^{-4}$ & $0.2 \times 10^{-4}$ & 2 \\
\hline $\mathrm{D}_{\mathrm{N} 2}$ & $\mathrm{~m}^{2} \mathrm{~d}^{-1}$ & $2.1 \times 10^{-4}$ & $0.42 \times 10^{-4}$ & 2 \\
\hline$D_{M}$ & $m^{2} d^{-1}$ & $1.5 \times 10^{-4}$ & $0.3 \times 10^{-4}$ & 2 \\
\hline $\mathrm{D}_{\mathrm{f}} / \mathrm{D}$ & - & 0.8 & 0.16 & 2 \\
\hline
\end{tabular}


